The impact of dissolved organic carbon and bacterial respiration on pCO2 in experimental sea ice

Zhou, Jiayun; Kotovitch, Marie; Kaartokallio, Hermanni; Moreau, Sebastien; Tison, Jean-Louis; Kattner, Gerhard; Dieckmann, Gerhard S.; Thomas, David N.; Delille, Bruno

\title{
Progress in Oceanography
}

DOI:

10.1016/j.pocean.2015.12.005

Published: 01/02/2016

Peer reviewed version

Cyswllt i'r cyhoeddiad / Link to publication

Dyfyniad o'r fersiwn a gyhoeddwyd / Citation for published version (APA):

Zhou, J., Kotovitch, M., Kaartokallio, H., Moreau, S., Tison, J-L., Kattner, G., Dieckmann, G. S., Thomas, D. N., \& Delille, B. (2016). The impact of dissolved organic carbon and bacterial respiration on pCO2 in experimental sea ice. Progress in Oceanography, 141, 153-167. https://doi.org/10.1016/j.pocean.2015.12.005

\footnotetext{
Hawliau Cyffredinol / General rights

Copyright and moral rights for the publications made accessible in the public portal are retained by the authors and/or other copyright owners and it is a condition of accessing publications that users recognise and abide by the legal requirements associated with these rights.

- Users may download and print one copy of any publication from the public portal for the purpose of private study or research.

- You may not further distribute the material or use it for any profit-making activity or commercial gain

- You may freely distribute the URL identifying the publication in the public portal ?
}

Take down policy

If you believe that this document breaches copyright please contact us providing details, and we will remove access to the work immediately and investigate your claim. 


\section{The impact of dissolved organic carbon and bacterial respiration on $\mathbf{p C O}_{2}$}

2 in experimental sea ice

4 Zhou, J., ${ }^{1,2,3}$, M. Kotovitch ${ }^{1,2}$, H. Kaartokallio ${ }^{4}$, S. Moreau ${ }^{5}$, J.-L. Tison ${ }^{1}$, G. Kattner ${ }^{6}$, G. 5 Dieckmann $^{6}$, D.N. Thomas ${ }^{4,7}$, B. Delille ${ }^{2}$

$7 \quad{ }^{1}$ Laboratoire de glaciologie, DSTE, Université Libre de Bruxelles, Belgium

$8 \quad{ }^{2}$ Unité d'océanographie chimique, MARE, Université de Liège, Belgium

$9 \quad{ }^{3}$ Division of Earth and Ocean Sciences, Duke University, Durham, NC, USA

${ }^{4}$ Marine Research Centre, Finnish Environment Institute (SYKE), Helsinki, Finland

$11{ }^{5}$ Georges Lemaitre Centre for Earth and Climate Research, Earth and Life Institute, Université 12 catholique de Louvain, Louvain-la-Neuve, Belgium ${ }^{6}$ Alfred Wegener Institute Helmholtz Center for Polar and Marine Research, Bremerhaven, 14 Germany

${ }^{7}$ School of Ocean Sciences, Bangor University, Menai Bridge, United Kingdom

\section{Abstract}

Previous observations have shown that the partial pressure of carbon dioxide $\left(\mathrm{pCO}_{2}\right)$ in sea ice brines is generally higher in Arctic sea ice compared to those from the Antarctic sea ice, especially in winter and early spring. We hypothesized that these differences result from the higher dissolved organic carbon (DOC) content in Arctic seawater: Higher concentrations of DOC in seawater would be reflected in a greater DOC incorporation into sea ice, enhancing bacterial respiration, which in turn would increase the $\mathrm{pCO}_{2}$ in the ice. To verify this hypothesis, we performed an experiment using two series of mesocosms: one was filled with seawater (SW) and the other one with seawater with an addition of filtered humic-rich river water (SWR). The addition of river water increased the DOC concentration of the water from a median of 142 $\mu \mathrm{mol} \mathrm{L}{ }^{-1}$ in SW to $249 \mu \mathrm{mol} \mathrm{L}^{-1}$ in SWR. Sea ice was grown in these mesocosms under the same physical conditions over 19 days. Microalgae and protists were absent, and only bacterial activity has been detected. We measured the DOC concentration, bacterial respiration, total

31 alkalinity and $\mathrm{pCO}_{2}$ in sea ice and the underlying seawater, and we calculated the changes in dissolved inorganic carbon (DIC) in both media. We found that bacterial respiration in ice was 
higher in SWR: median bacterial respiration was $25 \mathrm{nmol} \mathrm{C} \mathrm{L}{ }^{-1} \mathrm{~h}^{-1}$ compared to $10 \mathrm{nmol} \mathrm{C} \mathrm{L}-1$ $\mathrm{h}^{-1}$ in SW. $\mathrm{pCO}_{2}$ in ice was also higher in SWR with a median of $430 \mathrm{ppm}$ compared to 356 $\mathrm{ppm}$ in SW. However, the differences in $\mathrm{pCO}_{2}$ were larger within the ice interiors than at the surfaces or the bottom layers of the ice, where exchanges at the air-ice and ice-water interfaces might have reduced the differences. In addition, we used a model to simulate the differences of $\mathrm{pCO}_{2}$ and DIC based on bacterial respiration. The model simulations support the experimental findings and further suggest that bacterial growth efficiency in the ice might be 0.15-0.2. It is thus credible that the higher $\mathrm{pCO}_{2}$ in Arctic sea ice brines compared with those from the Antarctic sea ice were due to an elevated bacterial respiration, sustained by higher riverine DOC loads. These conclusions should hold for locations and time frames when bacterial activity is relatively dominant compared to algal activity, considering our experimental conditions.

\section{Highlights (85 characters per highlight)}

- Brine concentration/dilution causes the largest temporal changes of $\mathrm{pCO}_{2}$ in ice

- Elevated BR due to riverine DOC addition increases $\mathrm{pCO}_{2}$ in sea ice

- Gas exchange and the buffer effect further affect the bacterial impact on $\mathrm{pCO}_{2}$

\section{Keywords (up to six)}

Sea ice, dissolved organic matter, carbon dioxide, bacterial activity, gas exchange

\section{Introduction}

Sea ice is formed from the freezing of seawater and covers about $6 \%$ of the Earth's ocean surface. It has a heterogeneous structure composed of a matrix of pure ice and brine inclusions. Although sea ice is currently assumed to be impermeable to gas exchange in large-scale climate models, theoretical considerations (Golden et al., 1998) and pioneer gas measurements (Gosink et al., 1976) indicate that sea ice may be permeable under specific conditions of ice temperature and salinity. Measurements of $\mathrm{pCO}_{2}$ in sea ice and brines have been intensified in both the Arctic (Crabeck et al., 2014; Geilfus et al., 2012a; Miller et al., 2011a, 2011b) and the Southern Ocean (Delille, 2006; Delille et al., 2007; Geilfus et al., 2014). The motivation for these measurements is to better understand the role of sea ice in the carbon cycle, including its role 
in air-sea exchange of $\mathrm{CO}_{2}$, and the potential feedback effects between the changing ice cover, $\mathrm{CO}_{2}$ fluxes, and climate change.

Current measurements indicate that sea ice may act as a source or a sink for atmospheric $\mathrm{CO}_{2}$, depending on the interplay of four processes:

(i) Brine concentration and dilution are associated with changes in ice temperature. When cooling a sea ice sample, some of the liquid water of the brine freezes, reducing the brine volume and inclusions and increasing the concentration of the impurities in the brine - this is the so-called brine concentration. In contrast, when warming a sea ice sample, some of the pure ice melts, increasing the volume of the brine inclusion and decreasing the concentration of the impurities in brine - this is the so-called brine dilution (Hunke et al., 2011; Notz and Worster, 2009).

(ii) Biological activity, which includes the photosynthesis and respiration by organisms, respectively, consumes and produces $\mathrm{CO}_{2}$ (e.g., Papadimitriou et al., 2007).

(iii) The precipitation and dilution of calcium carbonate, which produces and consumes $\mathrm{CO}_{2}$, respectively (Dieckmann et al., 2010, 2008; Geilfus et al., 2013), effectively alters the $\mathrm{CO}_{2}$ budget in the ice when sea ice is semi-permeable, and when the calcium carbonate precipitates remain in the ice while the generated $\mathrm{CO}_{2}$ is rejected into the under-ice water (Delille et al., 2014; Rysgaard et al., 2007) or to the atmosphere (Geilfus et al., 2013; Loose et al., 2011).

(iv) Gas transport through sea ice is not yet well constrained, but it is commonly assumed that sea ice is permeable for gas transport when its brine volume fraction is above $5 \%$ (Golden et al., 1998). Brine drainage - the intensity of which is estimated using Raleigh numbers - is thought to be a significant process for ice-water exchange (Notz and Worster, 2009), while gas bubble formation potentially plays an important role in air-ice exchange (Moreau et al., 2014; Zhou et al., 2013). The diffusion of $\mathrm{CO}_{2}$ through sea ice also affects air-ice exchange, but seems to be much slower, i.e., less efficient than gas bubble transport (Kotovitch et al., submitted; Loose et al., 2014).

Previous studies indicate that, for a given brine temperature, the $\mathrm{pCO}_{2}$ in sea ice brine in the Arctic Ocean (Geilfus et al., 2014, 2012a) was generally higher than that in the Southern Ocean (Delille et al., 2014; Geilfus et al., 2014), especially when the average ice temperature was below $-4^{\circ} \mathrm{C}$ - which generally corresponds to the winter and early spring period (Figure 1 ). In this study, we hypothesized that the higher $\mathrm{pCO}_{2}$ was associated to the more intense bacterial respiration in the Arctic sea ice, due to the large input of riverine particulate organic carbon 
94 (POC) and dissolved organic carbon (DOC) in the Arctic Ocean (e.g., Dittmar and Kattner 95 (2003); Hansell et al. (2009)). Ice temperature is unlikely to explain the Arctic-Antarctic discrepancies, because at a given temperature, the effect of brine concentration on $\mathrm{pCO}_{2}$ is expected to be the same in both hemispheres. However, the impact of DOC availability on bacterial respiration and $\mathrm{pCO}_{2}$ in sea ice has not yet been demonstrated by systematic DOC and POC measurements in parallel. Therefore we performed an indoor experiment using two series of mesocosms: One was filled with seawater (SW) and another with seawater and an addition of filtered river water (SWR) to simulate riverine DOC input. The objective of the present paper is to verify whether or not higher DOC concentrations in seawater, due to an addition of riverine DOC, induce larger DOC concentrations in sea ice, which in turn enhance bacterial respiration and $\mathrm{pCO}_{2}$ in the ice.

\section{Material and methods}

\subsection{Experimental setting, and sampling routine and initial conditions}

The experimental setting and sampling routine has been described in Zhou et al. (2014). Briefly, we ran a 19-day experiment in the Arctic Environmental Test Basin facility of the Hamburg Ship Model Basin (www.hsva.de) from May to June 2012. We used 21 polyethylene experimental mesocosms each with a volume of $1.2 \mathrm{~m}^{3}$. Eleven of the mesocosms were filled with $1000 \mathrm{~L}$ of seawater from the North Sea (referred here after as SW), and the remaining ten were filled with $900 \mathrm{~L}$ of seawater from the North Sea and $100 \mathrm{~L}$ of filtered river water collected at a peat-dominated catchment of the River Kiiminkijoki, in Finland (referred here after as SWR).

The addition of river water caused a significantly higher DOC concentration in the SWR mesocosms (paired t-test, $\mathrm{p}<0.001$ ): Median salinity-normalized DOC concentrations were 140 $\mu \mathrm{mol} \mathrm{L}{ }^{-1}$ in SW and $251 \mu \mathrm{mol} \mathrm{L}{ }^{-1}$ in SWR (salinity 30.9), with a standard deviation of $3 \%$ in the SW mesocosms and $9 \%$ in SWR. However, salinity-normalized dissolved organic nitrogen (DON) was not significantly different between both mesocosm series (median of $16 \mu \mathrm{mol} \mathrm{L}-1$ in SW and $19 \mu \mathrm{mol} \mathrm{L}^{-1}$ in SWR), because its concentration in river and North Sea water were almost the same, and the standard deviation was relatively high (17\%) in both SW and SWR mesocosms. The carbonate chemistry was also not significantly different for both mesocosm series: median salinity-normalized total alkalinity was $2314 \mu \mathrm{mol} \mathrm{kg}^{-1}$ in SW and $2336 \mu \mathrm{mol}$

$124 \mathrm{~kg}^{-1}$ in SWR; median salinity-normalized dissolved inorganic carbon (DIC) were $2113 \mu \mathrm{mol}$ $\mathrm{kg}^{-1}$ in SW and and $2161 \mu \mathrm{mol} \mathrm{kg}-1$ in SWR; and median $\mathrm{pCO}_{2}$ were $212 \mathrm{ppm}$ in $\mathrm{SW}$ and 231 
ppm in SWR, respectively. The salinities of the SWR mesocosms were adjusted to the SW values by adding aquarium standard salt $\left(\right.$ Tropic Marin $\left.{ }^{\circledR}\right)$. Nitrate $\left(\mathrm{NO}_{3}{ }^{-}\right)$and phosphate $\left(\mathrm{PO}_{4}{ }^{3-}\right.$ ) concentrations were also adjusted to concentrations that would not limit bacterial growth in both series of mesocosms, and that were representative of areas in both Arctic and Southern Oceans (Zhou et al., 2014).

131 Ice was grown from day 0 to 14 , during which the air temperature was maintained at $-14{ }^{\circ} \mathrm{C}$, 132 and then the air temperature was increased to $-1{ }^{\circ} \mathrm{C}$ to trigger a decay phase. We collected ice,

133 brine and seawater at various occasions from day 0 to day 19 for the measurements of 134 temperature, salinity, DOC, inorganic nutrients, bacterial abundance, and bacterial activity 135 (Zhou et al., 2014), as well as $\mathrm{pCO}_{2}$ and total alkalinity.

136 Because the physical constraints were similar for both the SW and SWR mesocosms, we expected bacterial activity to be the only process affecting the difference of $\mathrm{pCO}_{2}$ in both water and ice. Median bacterial abundance was 922 cells L $^{-1}$ in SW at the beginning of the experiment and was not significantly different from the 972 cells $\mathrm{L}^{-1}$ in SWR. Protists and active photoautotrophs were absent in the experiment (checked by microscopy and epifluorescence microscopy, respectively). As a corollary, there was no autochthonous production of DOC and our experiment focuses on the impact of the additional allochtonous DOC (added by the river water) on bacterial respiration and $\mathrm{pCO}_{2}$ in both water and ice. Although photoautotrophs were absent in our experiments, we believe that it would not drastically affect the verification of the hypothesis, because the largest observed difference of $\mathrm{pCO}_{2}$ in brine corresponds to the lowest ice temperature (Figure 1), which mostly correspond to the ice interior (over winter and early spring) where algal activity is relatively limited compared to the bacterial activity (Baer et al., 2015).

\subsection{Brine volume fraction and Raleigh number}

150 The brine volume fraction is used here as a proxy of sea ice permeability and is calculated from 151 the ice temperature and salinity following the relationship of Cox and Weeks (1983). We assume that the sea ice was permeable for a brine volume fraction exceeding $5 \%$ (Golden et al., 1998). We also calculated the Rayleigh number ( $\mathrm{Ra})$, which is a proxy for brine convection as described by Notz and Worster (2008). Theoretically, convection is possible in an ice layer

155 (of a thickness $h$ ) when Ra exceeds 1 and decreases from the top to the bottom of that layer 156 (Notz, personal communication). We thus simply assume the critical Ra being 1 following those 157 theoretical considerations. 
159 Samples for the determination of dissolved organic carbon (DOC) and total dissolved nitrogen 160 (TDN) were stored frozen $\left(-20^{\circ} \mathrm{C}\right.$ ) in glass vials (Wheaton; pre-combusted at $500{ }^{\circ} \mathrm{C}$ for $5 \mathrm{~h}$ ) 161 and determined by high temperature catalytic oxidation and subsequent non-dispersive infrared 162 spectroscopy and chemiluminescence detection, respectively (TOC-VCPN, Shimadzu). After 163 each batch of five samples, one reference standard (DOC-DSR, Hansell Research Lab, 164 University of Miami, US), one ultrapure-water blank and one potassium hydrogen phthalate 165 standard for DOC and potassium nitrate for TDN were measured. DON concentrations were calculated as difference of TDN and inorganic nitrogen. The accuracy of the measurements was $167 \pm 5 \%$.

\subsection{Bacterial respiration}

Bacterial respiration has been calculated as the difference between the bacterial carbon demand and bacterial production. We measured bacterial production (see below) and assumed that it represented $34.8 \%$ (bacterial growth efficiency, BGE) of the bacterial carbon demand to deduce the bacterial respiration. BGE was derived as mean estimate from available sources for sea-ice bacteria or bacteria in very cold temperatures (Kuparinen et al., 2011; Nguyen and Maranger, 2011; Rivkin and Legendre, 2001).

For the bacterial production measurements, samples containing a known amount of crushed ice and sterile-filtered seawater (Kaartokallio, 2004) were prepared in a cold room as follows: each intact 5-10 cm ice core section was crushed using a spike and electrical ice cube crusher. Approximately $10 \mathrm{~mL}$ of crushed ice was weighed in a scintillation vial. To better simulate the brine pocket salinity and ensure an even distribution of labelled substrate, $3 \pm 1 \mathrm{~mL}$ of sterile filtered (through a $0.2 \mu \mathrm{m}$ filter) seawater from the sample bags were added to the scintillation vials. Bacterial production was measured immediately after sample collection using the $\left[{ }^{3} \mathrm{H}\right]-$ thymidine incorporation method (Fuhrman and Azam, 1982, 1980). Two aliquots and a formaldehyde-fixed absorption blank were amended with $\left[{ }^{3} \mathrm{H}\right]$-thymidine (PerkinElmer, USA, specific activity $20 \mathrm{Ci} \mathrm{mmol}^{-1}$ ). The added concentration was $30 \mathrm{nmol} \mathrm{L}^{-1}$ for all sample types. The samples were incubated in the dark at $-0.6{ }^{\circ} \mathrm{C}$ on crushed ice in an insulated container according to the projected level of activity: ice samples were incubated between $19 \mathrm{~h}$ and $22 \mathrm{~h}$, water and brine samples between $4 \mathrm{~h}$ and $6 \mathrm{~h}$. The incubations were stopped by addition of formaldehyde and samples were processed using the standard cold-TCA extraction and filtration procedure. Samples were extracted for 15 minutes in ice-cold $5 \%$ TCA and labelled macromolecules collected on $0.2 \mu \mathrm{m}$ mixed cellulose ester membrane filters (Osmonics). Filters 
191 were rinsed five times with ice-cold 5\% TCA and placed in clean scintillation vials. A Wallac

192 WinSpectral 1414 counter and InstaGel (Perkin-Elmer) cocktail were used in scintillation counting. Bacterial production was calculated using a cell conversion factor of $2.09 \times 10^{18}$ cells $194 \mathrm{~mol}^{-1}$ (Smith and Clement, 1990), a cell volume of $0.3 \mu \mathrm{m}^{3}$ (Kaartokallio, 2004; Smith and

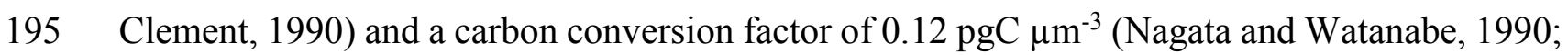
196 Pelegrí et al., 1999).

\section{$2.5 \mathrm{pCO}_{2}$}

The $\mathrm{pCO}_{2}$ of the seawater was measured in-situ using a custom-made equilibration system, which is described in Delille et al. (2014). Briefly, the system consists of a membrane contractor equilibrator (Membrana ${ }^{\circledR}$, Liqui-cell) that is connected to a non-dispersive infrared gas analyser (IRGA, Li-Cor ${ }^{\circledR} 6262$ ) via a closed air loop. Seawater and air flow rates through the equilibrator and IRGA were approximately $2 \mathrm{~L} \mathrm{~min}^{-1}$ and $3 \mathrm{~L} \mathrm{~min}^{-1}$, respectively. Temperature was simultaneously measured in situ and at the outlet of the equilibrator using Li-Cor ${ }^{\circledR}$ temperature sensors. Temperature correction of $\mathrm{pCO}_{2}$ was applied assuming that the relation of CopinMontegut (1988) is valid at low temperature and high salinity. Data were stored on a Li-Cor ${ }^{\mathbb{B}}$ Li-1400 data logger. All devices, except the peristaltic pump, were enclosed in an insulated box that contained a $12 \mathrm{~V}$ power source providing enough warming to keep the inside temperature above $0{ }^{\circ} \mathrm{C}$. Uncertainty is less than $5 \mu$ atm.

The method for the $\mathrm{pCO}_{2}$ measurements in ice is the same as in Geilfus et al. (2012b), but with longer equilibrium times following Crabeck et al. (2014). The ice samples were cut with a band saw, in a cold room at $-25^{\circ} \mathrm{C}$ and adjusted to the container's inner volume $(4 \mathrm{~cm} \mathrm{x} 4 \mathrm{~cm} \mathrm{x} 4.4$ $\mathrm{cm})$. The sample was sanded down using fine-grained sandpaper so that it fitted tightly into the container to minimise the headspace volume. Then, the container was placed into a Dewar vessel filled with ethanol, which was cooled to $-30{ }^{\circ} \mathrm{C}$ with liquid nitrogen. The container was then connected to the extraction line (tap closed). The line was first evacuated down to a pressure of $10^{-3}$ Torr, after which the container was evacuated for $5 \mathrm{~min}$. The low temperature of the vessel insures sea ice impermeability, i.e., the $\mathrm{CO}_{2}$ of the ice was not vacuumed during this process. The standard gas was then injected into the container at 1013 mbar. The container was subsequently removed from the extraction line (tap closed), placed in a thin plastic bag and submerged in a thermostatic bath (set to the in situ temperature, i.e., that was measured on the ice samples directly after the extraction). After $20 \mathrm{~h}$ of equilibrium, the container was placed in a Dewar filled with ethanol cooled at the in situ temperature and reconnected to the evacuated $\left(10^{-3}\right.$ Torr) extraction line. At the same time, a water trap consisting of a Dewar filled with an 
ethanol bath at $-65{ }^{\circ} \mathrm{C}$ was placed on the line just before the GC. The gas was finally injected into the GC. Immediately after the injection, the ice sample temperature was measured using a calibrated thermometer (Testo $720 \AA$ ). Reproducibility of the measurement is $2.9 \%$.

\subsection{TA and DIC}

Total alkalinity (TA) was measured on melted bulk ice and seawater samples. Ice cores were cut at a $2 \mathrm{~cm}$-depth resolution (about $50 \mathrm{~g}$ of ice for each section) and melted. Melted bulk ice and seawater samples were poisoned with a solution of supersaturated $\mathrm{HgCl}_{2}$ and then stored in the dark, until analysis (one year after the sampling). TA was measured by open-cell titration with $0.11 \mathrm{M} \mathrm{HCl}$ and the endpoints were determined according to Gran (1952). Routine analyses of Certified Reference Materials (provided by A. G. Dickson, Scripps Institution of Oceanography) ensured that the uncertainty of the TA measurements was less than $4 \mu \mathrm{mol} \mathrm{kg}{ }^{-1}$. Dissolved inorganic carbon (DIC) was calculated from TA and $\mathrm{pCO}_{2}$ using $\mathrm{CO} 2 \mathrm{SYS}$ (Lewis and Wallace, 1998), the $\mathrm{CO}_{2}$ acidity constants of Mehrbach et al. (1973) refitted according to Dickson and Millero (1987) and other constants advocated by DOE (1994). We assumed that the $\mathrm{CO}_{2}$ dissociation constants were applicable at sub-zero temperatures as suggested by Marion (2001) and Delille et al. (2007). To compare DIC in seawater and in melted bulk ice, we normalized the DIC values to a salinity of $7\left(\mathrm{DIC}_{7}\right)$, for consistency with previous studies. The salinity of 7 is also the mean salinity of the ice in this study. Uncertainty of $\mathrm{DIC}_{7}$ deduced from the reproducibility of TA and $\mathrm{pCO}_{2}$ has been evaluated to be $0.8 \mu \mathrm{mol} \mathrm{kg}{ }^{-1}$ using Monte Carlo procedure (Anderson, 1976).

\subsection{Differences between the SW and SWR series and statistical tests}

The ice thickness was different between the SW and SWR mesocosms (up to $3 \mathrm{~cm}(15 \%)$ of difference) at day 14 and day 15 . This was due to an unavoidable temperature gradient in the experimental basin (Zhou et al., 2014). In spite of the gradient of temperature in the experimental basin, we do not think that it has affected the results. The SW and SWR mesocosms sampled the same day were adjacent mesocosms located on the same row (minimizing the differences in physical conditions). For day-to-day sampling, the SW/SWR pairs of mesocosms were randomly selected in space. In spite of that random selection, we still could see a trend in the physical parameters (Zhou et al., 2014), which means that the temperature gradient in the experimental basin did not significantly bias our results. However,

254 to be rigorous, when the ice thicknesses were different for SW and SWR, we calculated the 255 difference of the parameters (e.g., $\mathrm{pCO}_{2}$ ) on normalized ice depth, and then multiplied the 
normalized ice depth by the ice thickness of the SW series. In addition, two parameters were assumed to be similar (i.e., no significant difference between the SW and SWR series), when a minimum similarity score of 0.95 was achieved.

\section{Results}

\subsection{Physical sea ice conditions}

As described in Zhou et al. (2014), the differences in the physical properties of the ice between the SW and SWR mesocosms were insignificant. The brine volume fraction was above $5 \%$ during the whole experiment, which suggests that the ice was always permeable (Golden et al., 1998). The maxima in the brine volume fraction were all found at the bottom of the ice, while the minima were found in the ice interior, and decreased from $13.3 \%$ on day 1 to $5.7 \%$ on day 14 , but increased from day 15 onwards, due to the increase of the air temperature from $-14{ }^{\circ} \mathrm{C}$ to $-1{ }^{\circ} \mathrm{C}$. The Rayleigh numbers were higher than 1 , indicating favourable conditions for brine convection at all ice depths on day 2, and thereafter only at the bottom of the ice until day 14 . From day 15 onwards, the Rayleigh numbers were always below 1, indicating that brine convection was unlikely (Figure 2). A large difference of Ra has been observed at the bottom of the ice between SW and SWR mesocosms, from day 6 to 14, and was likely due to an underestimation of salinity in SWR, and the propagation of that bias in the calculation of Ra (Zhou et al., 2014), but is not significant for the purpose of the present study.

\subsection{DOC and DON}

DOC concentrations in sea ice and water and their difference between the SW and the SWR mesocosms have been presented and discussed in Zhou et al. (2014) and Jørgensen et al. (2015). Most importantly, the salinity-normalized DOC concentrations in the underlying water were higher in the SWR mesocosms than in the SW mesocosm during the experiment (ppaired t-test, $\mathrm{p}<0.001$ ); the medians were $142 \mu \mathrm{mol} \mathrm{L}{ }^{-1}$ in SW and $246 \mu \mathrm{mol} \mathrm{L}^{-1}$ in SWR (salinity of 30.9), which were similar to the initial conditions. Median DOC concentrations in ice were $71 \mu \mathrm{mol}$ $\mathrm{L}^{-1}$ in SW and $109 \mu \mathrm{mol} \mathrm{L}-1$ in SWR. These are equivalent to $287 \mu \mathrm{mol} \mathrm{L}-1$ and $409 \mu \mathrm{mol} \mathrm{L}^{-1}$ respectively, once normalized to a salinity of 30.9 as for the underlying water (paired t-test, $\mathrm{p}<0.001$ ); they are higher than the values in water, which indicate a preferential retention of DOC in sea ice.

DON concentrations have not been systematically measured as for DOC ( $\mathrm{n}=18$ in water and 15 in ice for DON compared to $n=20$ and 110 , respectively, for DOC (SW+SWR)). The limited 
number of data we have show that the salinity-normalized DON concentrations were not significantly different in SW and SWR mesocosms, not before the experiment (median of 21 $\mu \mathrm{mol} \mathrm{L} \mathrm{L}^{-1}$ ), or during the experiment, in both the water and ice (medians of $17 \mu \mathrm{mol} \mathrm{L}^{-1}$ and 21 $\mu \mathrm{mol} \mathrm{L} \mathrm{L}^{-1}$, respectively) (data not shown). No significant trend in DON has been detected in the water and the ice over the experiment.

\subsection{Bacterial activity}

Median bacterial abundance in the underlying water increased over the experiment, reaching 1470 cells $\mathrm{L}^{-1}$ in SW and 1505 cells $\mathrm{L}^{-1}$ in SWR. This difference was not significant, despite the significantly higher bacterial production (BP) in the SWR mesocosms (paired t-test, $\mathrm{p}=0.007$ ), with a median of $69 \mathrm{nmolC} \mathrm{L}^{-1} \mathrm{~h}^{-1}$ in SWR compared to $51 \mathrm{nmolC} \mathrm{L}^{-1} \mathrm{~h}^{-1}$ in SW. Bacterial respiration (BR) in water was also higher in the SWR mesocosms (paired t-test, $\mathrm{p}=0.027$ ), with a median of $98 \mathrm{nmolC} \mathrm{L}^{-1} \mathrm{~h}^{-1}$ in SW and $129 \mathrm{nmolC} \mathrm{L}^{-1} \mathrm{~h}^{-1}$ in SWR, respectively (Figure 3a, left).

Median bacteria abundance in ice was 299 cells $\mathrm{L}^{-1}$ in SW and 352 cells $\mathrm{L}^{-1}$ in SWR, with a net loss of 24 cells $\mathrm{L}^{-1} \mathrm{~d}^{-1}$ in SW and 16 cells $\mathrm{L}^{-1} \mathrm{~d}^{-1}$ in SWR over the experiment. Median BP was 5 nmolC $\mathrm{L}^{-1} \mathrm{~h}^{-1}$ in SW and $13 \mathrm{nmolC} \mathrm{L}^{-1} \mathrm{~h}^{-1}$ in SWR, and median BR, $10 \mathrm{nmol} \mathrm{L}^{-1} \mathrm{~h}^{-1}$ in SW and $25 \mathrm{nmol} \mathrm{L} \mathrm{L}^{-1} \mathrm{~h}^{-1}$ in SWR (Fig. 3a, right). To compare bacterial activity in ice with that in seawater, we assumed that all these parameters were conservative against salinity. Once normalized to a salinity of 30.9 , median bacterial abundance reached 1220 cells $\mathrm{L}^{-1}$ in SW and 1440 cells $\mathrm{L}^{-1}$ in SWR; median BP of $23 \mathrm{nmolC} \mathrm{L}^{-1} \mathrm{~h}^{-1}$ in SW and $53 \mathrm{nmolC} \mathrm{L}^{-1} \mathrm{~h}^{-1}$ in SWR;

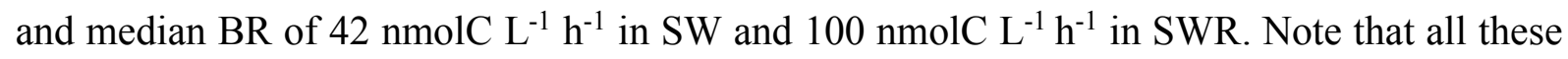
values were higher in SWR than in SW (paired t-test, $\mathrm{p}<0.001$ ), but lower than in seawater (paired t-test, $p<0.001$ for BP and BR in SWR; $p=0.001$ in SW; $p=0.004$ for bacterial abundance in SW but no significance has been found for bacterial abudnace in SWR). The vertical distribution of BR in ice was similar in the SW and SWR mesocosms (Figure 4): It increased from the top to the bottom of the ice. The difference between both mesocosm series generally increased from the top to the bottom of the ice, where the largest differences were observed.

\section{4 $\mathrm{DIC}_{7}$}

For data comparison with litterature, we normalized DIC to a salinity of 7. Differences of $\mathrm{DIC}_{7}$ between SW and SWR were not significant for both the under-ice water and the ice. $\mathrm{DIC}_{7}$ in seawater varied around a median value of $455 \mu \mathrm{mol} \mathrm{kg}$, when excluding the outlier of SWR on day 5 . Median $\mathrm{DIC}_{7}$ in ice for the same mesocosms was slightly higher than in seawater, 
reaching $486 \mu \mathrm{mol} \mathrm{kg}^{-1}$ (Figure 3). $\mathrm{DIC}_{7}$ in both media increased from day 2 to day 16 and then remained constant. $\mathrm{DIC}_{7}$ in the ice increased from the top to the bottom of the ice in $\mathrm{SW}$ and SWR mesocosms (Figure 5). At the bottom of the ice, it increased throughout the experiment and was always higher than the $\mathrm{DIC}_{7}$ of the under-ice water by an average of $40 \mu \mathrm{mol} \mathrm{kg}^{-1}$. The difference of $\mathrm{DIC}_{7}$ between SWR and SW was higher in the ice interior at $8 \mathrm{~cm}$ to $12 \mathrm{~cm}$ depth. For comparison with bacterial respiration in ice, median DIC in ice that is not salinitynormalized was $434 \mu \mathrm{mol} \mathrm{kg}{ }^{-1}$, which is equivalent to $400 \mu \mathrm{mol} \mathrm{L}-1$.

\section{$3.5 \mathrm{pCO}_{2}$}

$\mathrm{pCO}_{2}$ in water was not significantly different between both mesocosm series, with a median $\mathrm{pCO}_{2}$ of 270 ppm. $\mathrm{pCO}_{2}$ in ice was also not significantly different between both mesocosm series probably as a result of the large variability. Median $\mathrm{pCO}_{2}$ in ice was $360 \mathrm{ppm}$ with a large range spanning from $223 \mathrm{ppm}$ to $651 \mathrm{ppm}$ (Figure 3). Median $\mathrm{pCO}_{2}$ was higher in the ice than in seawater during ice growth (day 2 to day 14), despite similar concentrations of $\mathrm{DIC}_{7}$ in the seawater and in the ice and lower bacterial respiration in ice than in seawater (Figure $3 \mathrm{c}$, sections 3.3 and 3.4).

The $\mathrm{pCO}_{2}$ in ice had a similar temporal evolution in the SW and SWR mesocosms (Figures $3 \mathrm{c}$ and 6). Considering that the average atmospheric $\mathrm{pCO}_{2}$ was $460 \mathrm{ppm}$ during the experiment (Kotovitch et al. submitted), $\mathrm{pCO}_{2}$ in ice was at first under-saturated on day 2, and then became increasingly supersaturated until day 14, and then under-saturated again from day 15 onwards. Despite the similar temporal evolution of $\mathrm{pCO}_{2}$ in ice, $\mathrm{pCO}_{2}$ was generally higher in the SWR mesocosms, with a median value of $430 \mathrm{ppm}$ compared to the $356 \mathrm{ppm}$ in the SW mesocosms. The differences in $\mathrm{pCO}_{2}$ were generally higher from the top to the ice interior to about $8 \mathrm{~cm}$ depth, except on day 2, when the ice was relatively thin $(6 \mathrm{~cm})$; on days 5 and 19 , the difference of $\mathrm{pCO}_{2}$ at the bottom of the ice was likely biased due to the large difference of $\mathrm{CO}_{2}$ in the under-ice water (Figure 3c, left). Indeed, for days 5 and 19, the differences in $\mathrm{pCO}_{2}$ in the underice water between SW and SWR were 100 ppm and 86 ppm, respectively, while they generally approached $0 \mathrm{ppm}$ to $20 \mathrm{ppm}$ in the other mesocosms on all other sampling days (Figure $3 \mathrm{c}$, 346 left).

\section{Discussion}

The addition of river water led to an enrichment of the overall DOC concentrations in the SWR water, compared to SW, by a factor of $1.8\left(251 \mu \mathrm{mol} \mathrm{L}^{-1} / 140 \mu \mathrm{mol} \mathrm{L} \mathrm{L}^{-1}\right)$. The preferential 
Zhou et al., 2014) led to a salinity-normalized DOC concentration in ice that was higher than 352 the under-ice water $\left(409 \mu \mathrm{mol} \mathrm{L}{ }^{-1} / 287 \mu \mathrm{mol} \mathrm{L}^{-1}\right)$, but the difference of DOC enrichment between SWR and SW dropped to 1.4. The mechanisms underlying the preferential retention of DOC in sea ice is not fully understood, but other measurements during our experiment suggested that sea ice formation increases the lability of DOM in ice (Jørgensen et al., 2015). We therefore speculate that the more labile forms of DOM were better retained in sea ice than the more refractory ones. Because SWR contained a larger fraction of less labile terrestrial humic acids due to the addition of river water (Jørgensen et al., 2015), the DOC enrichment in ice in SWR was lower than in SW. We show below that the segregation of DOC between water and ice, in addition to the difference in temperature and salinity, likely contributed to the difference of bacterial activity in water and ice.

\subsection{Impact of riverine DOC addition on bacterial activity}

Available under-ice or partially ice covered water respiration estimates for Western Arctic vary from 19 to $39 \mathrm{nmol} \mathrm{C} \mathrm{L}{ }^{-1} \mathrm{~h}^{-1}$ (Kirchman et al., 2009; Nguyen and Maranger, 2011; Nguyen et al., 2012), which is an order of magnitude lower than our respiration estimate for water (median

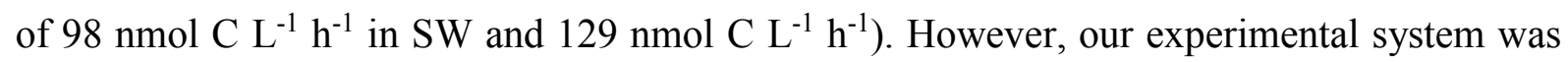
based on North Sea water with a high DOC content and added inorganic nutrients, which are both likely to support higher bacterial production than the more oligotrophic Arctic waters.

Assuming that bacterial activity took place 24 hours a day, a consumption of $23.3 \mu \mathrm{mol} \mathrm{C} \mathrm{\textrm {L } ^ { - 1 }}$ in SW and $31.5 \mu \mathrm{mol} \mathrm{C} \mathrm{L}{ }^{-1}$ in SWR is necessary to support the observed BP over the 19-day experiment. These represent $16 \%$ and $13 \%$ of the DOC pool, respectively. However, no significant changes have been detected in the DOC and DON concentrations in the under-ice water, or in the concentrations of inorganic nutrients (Zhou et al., 2014). A possible explanation is that bacteria used particulate organic matter (POM) as a carbon source for growth, despite the large pool of DOC. We did not measure POM concentrations in our experiment, but considering the absence of protists and active algae in seawater (in spite of the use of unfiltered seawater), we assumed that they died in the mesocosms, providing an additional source of carbon for bacterial growth. If this assumption is correct, BP would represent a smaller fraction of the DOC pool. The fraction was likely smaller than $3 \%$ in SW and $9 \%$ in SWR (the standard deviation of DOC concentrations among the mesocosms in the initial waters), because we would have detected significant changes otherwise. 
Although BP only represented a small fraction of the DOC pool, the addition of riverine DOC was the most plausible factor causing the significantly higher BP in the SW water, since all the other parameters (bacterial abundance, DON, inorganic nutrients, temperature, and presumably POC) were not significantly different between the SW and SWR mesocosms.

Published sea-ice respiration values originate from batch culture incubations using sea ice bacteria and are either derived from total Arctic sea ice community respiration measurements made in water phase incubations (Nguyen and Maranger, 2011) or from experimental systems with Baltic sea ice bacteria (Kuparinen et al., 2011). The estimated mean bacterial respiration in western Arctic ice was $50 \mathrm{nmol} \mathrm{C} \mathrm{L}^{-1} \mathrm{~h}^{-1}$ (Nguyen and Maranger, 2011) and in the Baltic Sea experiments approximately $80 \mathrm{nmol} \mathrm{C} \mathrm{L} \mathrm{L}^{-1} \mathrm{~h}^{-1}$ (Kuparinen et al., 2011). Our respiration estimate for ice was lower but of the same order of magnitude, despite major differences in methodology and experimental setup.

394 Bacterial activity in ice was different from that in the under-ice water. Bacterial abundance in sea ice was lower than in seawater, even when normalized to the same salinity. This has been observed before in similar experiments (Eronen-Rasimus et al., 2014) and likely resulted from the low ice temperature and high brine salinity, which favour the selection of psychrotrophic and psychrophilic bacteria (Helmke and Weyland, 1995).

Although the overall BP and bacterial abundance were lower in the ice than in the under-ice water, the ratio between both the SW and SWR mesocosms were more pronounced in the ice.

401 Bacterial production in SWR ice was 2.6 times higher than in SW, i.e., twice as high as the ratio (SWR/SW) observed in the water. Bacterial abundance was $20 \%$ higher than the SW ice, while no significant difference was found in the under-ice water. The only plausible factor driving these SWR/SW differences in ice was the higher DOC concentration in the SWR ice. Ice microalgae and protists were indeed absent (verified by microscopy) and no significant difference has been found in the DON concentrations and the physical properties of the ice.

407 It is curious as to why the differences of BP between both series of mesocosms were larger in 408 ice (SWR/SW ratio of 2.6) than in the water (ratio of 1.3), considering that the differences of 409 DOC concentrations between both mesocosms series decreased (ratio of 1.4 in ice compared to 4101.8 in water). This might be associated with the changes of the organic matter quality towards 411 more labile (bioavailable) forms in the ice during sea ice formation (Jørgensen et al., 2015). In 412 seawater, the addition of riverine DOC promoted higher BP in the SWR mesocosms. In sea ice, 413 the absolute DOC concentrations in SWR are not only higher than in SW, their lability might 414 also have increased compared to the SWR under-ice water; both might explain the larger 
415 difference of BP in ice between the SW and SWR mesocosms compared to the under-ice water.

416 DOC can directly contribute to bacterial growth as a carbon source; it may also support the 417 formation of exopolymeric substances (EPS) in growing sea ice (Aslam et al., 2012) - a 418 substance that is known to support microorganisms survival under the extreme conditions in 419 sea ice (Krembs et al., 2011). Further, it might also have favoured the development of a bacterial 420 community that is different from that in SW, as it has been observed by Eronen-Rasimus et al. 421 (2014).

\subsection{Similarities of DIC and $\mathrm{pCO}_{2}$ in ice in the $\mathrm{SW}$ and $\mathrm{SWR}$ mesocosms}

$\mathrm{DIC}_{7}$, which ranged from $423 \mu \mathrm{mol} \mathrm{kg}{ }^{-1}$ to $512 \mu \mathrm{mol} \mathrm{kg}^{-1}$ (in SW and SWR), was consistent with previous measurements on natural sea ice (Geilfus et al., 2014, 2012a; Rysgaard et al., 2007). $\mathrm{pCO}_{2}$ measurements for natural sea ice are scarce (Crabeck et al., 2014; Geilfus et al., 2014) and have been mainly obtained from the spring-summer period. Therefore, they were generally under-saturated relative to the atmosphere (i.e., below 400 ppm) (Crabeck et al., 2014; Geilfus et al., 2014). The $\mathrm{pCO}_{2}$ below $400 \mathrm{ppm}$ in ice during the decay period of our experiment was thus consistent with data from natural sea ice in spring and summer. Because of the lack of $\mathrm{pCO}_{2}$ measurements in natural ice during ice growth (and especially in autumn), we extended the comparison to the $\mathrm{pCO}_{2}$ in brine. Considering that the median ice temperature approached $-4.5^{\circ} \mathrm{C}$ during ice growth in this experiment (Zhou et al., 2014), and that temperature would correspond to a $\mathrm{pCO}_{2}$ of about $800 \mathrm{ppm}$ in Arctic sea ice brine (Figure 1), our in situ measurements of up to $724 \mathrm{ppm}$ are realistic.

435 Brine concentration and dilution and gas transport are likely to be the two main physical processes determining the similarities in the temporal and vertical pattern of $\mathrm{pCO}_{2}$ between the SW and SWR mesocosms (Figure 7). When plotting $\mathrm{pCO}_{2}$ in ice (SW and SWR) against the brine volume fraction, 10 mesocosms over 14 (represented by the circles on Figure 7) followed a decreasing trend $\left(r^{2}=0.836, p<0.03\right)$. These events include the very beginning of ice growth (day 2) and the ice growth and ice decay, except day 5, day 15 and two other outliers.

441 When cooling an ice sample, part of the water present in the brine inclusion will freeze, forming 442 a thicker surrounding pure ice matrix, which results in a higher concentration of the dissolved constituents into smaller brine inclusions. Therefore, $\mathrm{pCO}_{2}$ in sea ice became increasingly supersaturated, as the brine volume fraction decreased (from day 0 to day 14). In contrast, when warming an ice sample, the surrounding pure ice matrix is expected to melt, increasing the size of the brine inclusion and diluting the concentration of the dissolved constituents in the brines. 
$\mathrm{pCO}_{2}$ in sea ice thus became under-saturated as a result of the warming air temperature (from day 15 onwards) (Figures 6 and 7).

449 A rapid and one-time decrease of $\mathrm{pCO}_{2}$ in ice was observed on day 15. This was a particular event, occurring the day after the rapid increase of the air temperature, when the sea ice surface temperature sharply increased from $-10{ }^{\circ} \mathrm{C}$ to $-2{ }^{\circ} \mathrm{C}$ within 20 hours (Kotovitch et al., submitted). Different processes may explain this drastic decrease of $\mathrm{pCO}_{2}$, e.g., rapid release of gas bubbles (Zhou et al., 2013) and/or melt of $\mathrm{CO}_{2}$-poor surface ice layers and seepage of the meltwater (Geilfus et al., 2014), while the equilibrium of air-ice $\mathrm{pCO}_{2}$ occurs at a much slower rate. However, considering that day 15 was a particular event, it is unlikely that these $\mathrm{pCO}_{2}$ changes would be representative of those observed in natural conditions, so we will not further discuss the different plausible processes. Another outlier corresponded to the surface ice layer, where ice melt might have induced the low $\mathrm{pCO}_{2}(153 \mathrm{ppm})$. We currently have no explanation for the other outlier on day 5. Nevertheless, excluding these data, $\mathrm{pCO}_{2}$ was significantly correlated with the brine volume fraction, which indicates the major role of brine concentration and dilution in regulating $\mathrm{pCO}_{2}$ in ice.

462 To further demonstrate the importance of brine concentration and dilution for $\mathrm{pCO}_{2}$ dynamics, 463 we compared our values with the theoretical $\mathrm{pCO}_{2}$ considering only the changes in temperature and brine salinity. The theoretical $\mathrm{pCO}_{2}$ was calculated using the $\mathrm{CO} 2 \mathrm{SYS}$ program (Lewis and Wallace, 1998), the constants of Goyet and Poisson (1989), and the median temperature, salinity, total alkalinity and DIC in the parent water as initial conditions. We then used the median ice salinity (6.3) to calculate the brine volume fraction associated with each prescribed temperature. The theoretical $\mathrm{pCO}_{2}$ (red curve in Figure 7) reproduced the observations well between $10 \%$ and $20 \%$ of brine volume fraction (i.e., for about half of the data set), but overestimated the $\mathrm{pCO}_{2}$ in ice (up to $320 \mathrm{ppm}$, i.e., $44 \%$ ) for brine volume fractions below 10 $\%$. We attribute this overestimation to a significant escape of $\mathrm{CO}_{2}$ from the ice to the atmosphere during ice growth, which is not taken into account by the CO2SYS. Another explanation could be that the constants used in CO2SYS might be incorrect for sea ice, since 474 they were developed for temperature and salinity ranges of seawater, which are less extreme 475 than those of sea ice. However, the error in the estimate of $\mathrm{pCO}_{2}$ should approach $10 \%$ 476 according to Brown et al. (2014), when using TA and DIC as input parameters and the constants of Goyet and Poisson (1989). Hence, the error on the seawater-derived constant is not great enough to explain the difference in $\mathrm{pCO}_{2}$ between the $\mathrm{CO} 2 \mathrm{SYS}$ estimate and the observations, 
and therefore the escape of $\mathrm{CO}_{2}$ from the ice to the atmosphere remains the most plausible explanation.

The $\mathrm{DIC}_{7}$ profiles confirm that gas transport through sea ice affected $\mathrm{pCO}_{2}$ in ice (Figure 5), in addition to brine concentration and dilution. If sea ice would be a closed system, and the air-ice and ice-water exchange absent, DIC would be conservative against salinity. Hence, the value of $\mathrm{DIC}_{7}$ would be the same at all ice depths and in seawater. In our study, the ice was always permeable, with the brine volume fraction always above $5 \%$ (Golden et al., 1998). Gas exchange through the ice was thus possible and resulted in the deviation of the $\mathrm{DIC}_{7}$ in ice from the conservative behaviour. Values of $\mathrm{DIC}_{7}$ in ice that decreased from the bottom to the top of the ice indicate an escape of $\mathrm{CO}_{2}$ from the surface of the ice to the atmosphere (Figure 5) (Geilfus et al., 2013), and the observed decrease was also consistent with the air-ice fluxes we have measured during the growth phase of this experiment (Kotovitch et al., submitted). At the bottom of the ice, $\mathrm{DIC}_{7}$, which approached the values in the under-ice water, indicate that icewater exchange took place, which was possible through brine convection (high Rayleigh number, Figure 2). The $\mathrm{DIC}_{7}$ at the bottom of the ice increased throughout the entire period of ice growth, following the increase in $\mathrm{DIC}_{7}$ in the under-ice water as a result of the expulsion of DIC from the ice and bacterial respiration in the water during ice growth (Figure 3) (Moreau et al., submitted).

\subsection{Differences of DIC and $\mathrm{pCO}_{2}$ in ice between the $\mathrm{SW}$ and SWR mesocosms}

$\mathrm{DIC}_{7}$ and $\mathrm{pCO}_{2}$ in ice were higher in SWR than in SW. However, these differences between SW and SWR were not significant, despite the significantly higher BR in SWR, which should result in a larger accumulation of DIC and $\mathrm{CO}_{2}$ in SWR. Because the dynamics of $\mathrm{DIC}_{7}$ and $\mathrm{pCO}_{2}$ not only depend on bacterial activity, but also on physical processes (which were the same in both SW and SWR), the absence of significant differences might indicate that the physical processes have offset the bacterial impact on $\mathrm{DIC}_{7}$ and $\mathrm{pCO}_{2}$. For instance, if the differences of $\mathrm{DIC}_{7}$ and $\mathrm{pCO}_{2}$ were only due to bacterial activity, it is curious as to why the largest differences of $\mathrm{DIC}_{7}$ and $\mathrm{pCO}_{2}$ were observed in the ice interior (Figures 5 and 6), instead of at the bottom of the ice, where the difference in bacterial respiration was the largest. We interpret this as the result of gas exchange at the air-ice and ice-water interfaces, in addition to bacterial respiration. Since the difference of $\mathrm{pCO}_{2}$ was smaller between the bottom of the ice and the water than between the surface of the ice and the atmosphere, we conclude that ice-water exchange might have been more efficient than air-ice exchange in decreasing the difference of $\mathrm{pCO}_{2}$ between SWR and SW due to bacterial respiration. This is in agreement with the higher Rayleigh 
numbers observed at all times at the bottom of the growing sea ice, that indicate enhanced

513 convection and therefore exchanges with the under-ice water.

514 Bacterial respiration in bulk ice $\left(10 \mathrm{nmolC} \mathrm{L}^{-1} \mathrm{~h}^{-1}\right.$ in $\mathrm{SW}$ and $\left.25 \mathrm{nmolC} \mathrm{L}^{-1} \mathrm{~h}^{-1}\right)$ over 19 days only represent 1 to $3 \%$ of the stock of DIC $\left(400 \mu \mathrm{molC} \mathrm{L} \mathrm{L}^{-1}\right)$. It is therefore curious as to how such a low bacterial respiration may have caused a significant difference of $\mathrm{pCO}_{2}$ in the ice interior. An explanation could be the increase of the buffering effect of the carbonate system with the decrease of temperature and the increase of salinity in brine (brine concentration). The chemical buffer factor $\left(\beta=\Delta \mathrm{pCO}_{2} / \triangle \mathrm{DIC}\right)$ describes the change in $\mathrm{pCO}_{2}$ relative to the DIC change induced by an input (i.e., respiration) or output of dissolved $\mathrm{CO}_{2}$. It results from the interplay of equilibrium dissociation reactions of the carbonate system and is a function of several physico-chemical conditions (Delille et al., 2005; Frankignoulle, 1994). In a closed system, $\beta$ of brines increases significantly with decreasing temperature and the associated increase of brine salinity (Figure 8). Providing that bacterial respiration could explain the accumulation of DIC, an increase of DIC (even small) can result in a larger increase in $\mathrm{pCO}_{2}$ in cold saline brine compared to warmer underlying seawater (Figure 8). Considering that the difference of $\mathrm{DIC}_{7}$ in the ice interior approached $15 \mu \mathrm{mol} \mathrm{kg}{ }^{-1}$ (Figure 5) and that at $\beta$ approached 4 at $-4.5{ }^{\circ} \mathrm{C}$ (median temperature of the ice), an expected difference of $\mathrm{pCO}_{2}$ due to buffer factor changes should approach $60 \mathrm{ppm}$, which is relatively close to our observation

\section{0 (Figure 6).}

531 An alternate explanation is the underestimation of the bacterial respiration in bulk ice. We calculated bacterial respiration based on thymidine incorporation and different conversion factors. Our choice of BGE might have led to an underestimation of the estimate of bacterial respiration, as discussed in the next section,.

\subsection{Modelling the impact of bacterial respiration on $\mathrm{pCO}_{2}$ in ice}

In a closed system, bacterial respiration would induce an accumulation of DIC. In our semienclosed system, DIC also changed due to physical processes (ice-air and ice-water exchanges).

538 The interplay of these various processes makes it difficult to use a simple calculation to prove 539 (i) whether the difference in bacterial respiration caused the observed difference of DIC and $540 \mathrm{pCO}_{2}$ in the ice interior, and (ii) whether ice-air and ice-water exchanges have offset the 541 difference of DIC and $\mathrm{pCO}_{2}$ caused by respiration at the surface and the bottom of the ice, 542 respectively. 
543 To tackle these issues, we used the one-dimensional thermodynamic sea ice model of Moreau 544 et al. (2015) which includes ice-air gas exchanges and sea ice carbon dynamics. The model 545 features ice growth and melt, ice-air and ice-water exchanges, as well as representations of full 546 inorganic carbon and basic organic carbon dynamics within the ice. For the model simulations, 547 all the parameters used are those described in Moreau et al. (2015), except for biological activity 548 where primary production was shut down in the model runs. Bacterial respiration is prescribed 549 with the median values of the bacterial respiration for SW and SWR, i.e., $10 \mathrm{nmol} \mathrm{C} \mathrm{L}^{-1} \mathrm{~h}^{-1}$ in

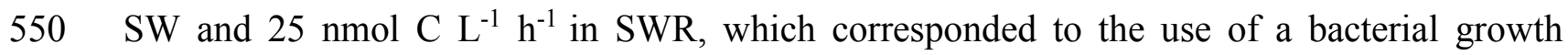
551 efficiency (BGE) of 0.348. Based on the initial conditions of the experiment, we prescribed the initial seawater TA and DIC concentrations (2244 $\mu \mathrm{mol} \mathrm{kg}^{-1}$ and $2039 \mu \mathrm{mol} \mathrm{kg}^{-1}$, respectively) and the initial sea ice TA and DIC concentrations $\left(847 \mu \mathrm{mol} \mathrm{kg} \mathrm{kg}^{-1}\right.$ and $\left.748 \mu \mathrm{mol} \mathrm{kg}^{-1}\right)$. The model was run over 19 days (duration of the experiment), with a 1-hour time step.

Because the model has different temporal and spatial resolutions than the observations, we decided to only compare the temporal evolution of the median values in the ice (modelled versus measured variables). Overall, the model reproduced the ice thicknesses, median ice temperatures and salinities, as well as the standing stock of DIC and the median $\mathrm{pCO}_{2}$ in ice in the same magnitude as those observed (Figure 9).

560 We first ran the model with the median values of the observed bacterial respiration for SW and SWR by using a BGE of 0.348 (Kuparinen et al., 2011). Given these bacterial respiration rates, the model reproduces the spatial pattern of the observed $\mathrm{DIC}_{7}$ standing stock and the median $\mathrm{pCO}_{2}$ (Figure 9) but not the magnitude of their difference between SW and SWR (Table 1). Therefore, we re-calculated bacterial respiration rates for SW and SWR using different BGE. Reducing BGE to 0.2 or 0.15 is plausible considering that BGE ranges from 0.05 to 0.6 (i.e., from $5 \%$ to $60 \%$ ), depending on the environmental conditions (e.g., the quality of the dissolved organic matter) (Del Giorgio and Cole, 1998; Nguyen et al., 2012; Rivkin and Legendre, 2001). Firstly, changing the BGE to 0.2 or 0.15 , and hence increasing the BR, did not change the total stock of DIC and the median $\mathrm{pCO}_{2}$ significantly (Figure 9, coloured curves), which supports our previous suggestions about the importance of the physical processes, such as brine concentration and dilution and gas transport, in regulating the dynamics of DIC and $\mathrm{pCO}_{2}$ in sea ice. However, changing the $\mathrm{BGE}$ to 0.2 or 0.15 enhanced the differences in $\mathrm{DIC}_{7}$ and $\mathrm{pCO}_{2}$ in ice between SW and SWR (Table 1). The modelled median difference of $\mathrm{DIC}_{7}$ fits the observations better when using a BGE of 0.2 and 0.15 (Table 1), and considering the reproducibility of $+/-0.8 \mu \mathrm{mol} \mathrm{kg}{ }^{-1}$ for DIC. The median difference of $\mathrm{pCO}_{2}$ is then higher than 
the observed differences in $\mathrm{pCO}_{2}$ between $\mathrm{SW}$ and $\mathrm{SWR}$, but considering that the model slightly overestimates the $\mathrm{pCO}_{2}$ near the ice surface (Kotovitch et al., submitted), differences in $\mathrm{DIC}_{7}$, rather than $\mathrm{pCO}_{2}$, would be a better indicator of the difference in bacterial impact. The model simulations therefore suggest that the bacterial respiration in ice might be up to 3 times higher than our previous estimate (Table 1).

581 The estimate of BGE for the entire period of the experiment $(0.15-0.2)$, as suggested by the model simulations, was lower than assumed. Our BGE estimate of 0.348 was based on empirical values obtained in liquid batch cultures in above-zero temperature (Kuparinen et al. 2011, Nguyen and Maranger 2011) combined with calculated temperature-dependent estimate (Rivkin \& Legendre 2001). Measuring bacterial process rates, especially respiration in sea-ice systems is complicated and direct respiration measurements were not available. The lower actual BGE suggested by the model in our experimental system compared to the previous published values is plausible because of the extremely low temperatures and high salinities in brine. Extreme conditions are in general forcing bacteria to invest more energy for survival than for growth. Along these lines, the actual BGE may vary throughout the ice growth, being lower during ice growth (where the conditions were more extreme), and higher during ice melt (where the conditions were milder). Further investigations are encouraged to verify this hypothesis. Furthermore, BGE in water column and ice may be different with higher BGE in water where conditions are less extreme. Higher BGE from 0.4 to 0.5 were suggested by Moreau et al. (submitted) for the under-ice water, in the same experimental system. Higher BGE for underice water would also lower the respiration estimate towards values measured in other studies (Kirchman et al. 2009, Nguyen and Maranger 2011, Nguyen et al. 2012) albeit in the high Arctic under different nutrient and dissolved organic carbon regimes.

599 The comparison of Figure 5 with Figure 10, and Figure 6 with Figure 11 shows that the model reproduced the temporal and spatial pattern of $\mathrm{DIC}_{7}$ and $\mathrm{pCO}_{2}$ well. $\mathrm{DIC}_{7}$ decreased from the bottom to the top of the ice due to air-ice gas exchange, except in the bottom most layer where $\mathrm{DIC}_{7}$ is underestimated due to an improper parameterization of heat and salt transfer in this 603 layer (Moreau et al., 2014; Vancoppenolle et al., 2010). $\mathrm{pCO}_{2}$ was supersaturated in the ice 604 during the entire ice growth period, except in the bottom layer where brine convection pulled 605 the $\mathrm{pCO}_{2}$ towards the under-saturated $\mathrm{pCO}_{2}$ value of the under-ice water. $\mathrm{pCO}_{2}$ in ice then also 606 became under-saturated, as it was observed, as a result of the increase of air temperature (and the related brine dilution). In addition, due to the higher bacterial respiration in SWR compared to $\mathrm{SW}, \mathrm{DIC}_{7}$ and $\mathrm{pCO}_{2}$ were higher in SWR than in $\mathrm{SW}$. The differences of $\mathrm{pCO}_{2}$ are alleviated 
at the bottom of the ice because of brine convection, and slightly at the top of the ice due to air-

610 ice gas exchange, but they are greater in the ice interior, which has to be associated with the 611 difference in bacterial respiration - the sole difference between the two runs: SW and SWR.

612 There are two main differences between the model simulations and the observations: The 613 absolute values of $\mathrm{DIC}_{7}$ and $\mathrm{pCO}_{2}$ are higher in the model than in the observations, and the 614 differences of $\mathrm{DIC}_{7}$ and $\mathrm{pCO}_{2}$ between SWR and SW present a smoother pattern in the model 615 than in the observations (Figures 5, 6, 9 and 10). Ice-air gas fluxes are currently not yet well 616 constrained in the model, resulting in a slight underestimation of the ice-air gas fluxes, and thus 617 an overestimation of the modeled DIC and $\mathrm{pCO}_{2}$ content in the ice (Kotovitch et al., submitted). 618 The smoother pattern in the modelled differences of $\mathrm{DIC}_{7}$ and $\mathrm{pCO}_{2}$ may result from the higher spatial and temporal resolution in the model than in the observations: Hourly time step and calculation on the 10 ice layers in the model compared to the almost daily sampling with 1 to 4 measured ice layers on each ice core.

In brief, differences exist between the model simulations and the observations, probably due to the parameterization of air-ice gas exchange and the difference of spatial and temporal resolution, but the model was able to reproduce the temporal and spatial patterns of $\mathrm{DIC}_{7}$ and $\mathrm{pCO}_{2}$, confirming therefore the importance of brine concentration and dilution, and gas transport in controlling their dynamics. Most importantly, the model reproduced the observed median difference of $\mathrm{DIC}_{7}$ in the ice by introducing the measured bacterial respiration (for a 628 lower BGE of 0.15 or 0.2 ), confirming that higher bacterial respiration could indeed cause a 629 larger accumulation of DIC and a larger $\mathrm{pCO}_{2}$ in the ice.

630 A corollary to the higher bacterial respiration, DIC and $\mathrm{pCO}_{2}$ in $\mathrm{SWR}$ in the model is an 631 enhanced ice-air $\mathrm{CO}_{2}$ flux during ice growth by $17 \%\left(1.68 \mathrm{mmol} \mathrm{m}^{-2} \mathrm{~d}^{-1}\right.$ and $1.97 \mathrm{mmol} \mathrm{m}^{-2} \mathrm{~d}^{-}$ $632{ }^{1}$ in SW and SWR, respectively), and a reduced $\mathrm{CO}_{2}$ flux during ice decay by $38 \%$ (-1.52 mmol $633 \mathrm{~m}^{-2} \mathrm{~d}^{-1}$ and $-0.93 \mathrm{mmol} \mathrm{m} \mathrm{m}^{-2} \mathrm{~d}^{-1}$ in SW and SWR, respectively) if we assume a BGE of 0.15 634 (simulated fluxes not shown). The enhanced $\mathrm{CO}_{2}$ fluxes during ice growth are obviously due to 635 the higher $\mathrm{pCO}_{2}$ in the ice resulting from the higher bacterial respiration. The negative $\mathrm{CO}_{2}$ 636 fluxes (i.e., from the air to the ice) are due to brine dilution (e.g., Nomura et al., 2010), and the 637 flux is less negative in SWR because the larger bacterial respiration in SWR better compensates 638 the effect of brine dilution. The integrated $\mathrm{CO}_{2}$ flux over the 19 days of the simulation was 0.16 $639 \mathrm{mmol} \mathrm{m} \mathrm{d}^{-1}$ and $1.04 \mathrm{mmol} \mathrm{m}^{-2} \mathrm{~d}^{-1}$ in SW and SWR, respectively. Hence, the addition of DOC 640 might have induced an air-ice $\mathrm{CO}_{2}$ flux that was more than 6 times higher than without the 641 addition of DOC. 
643 The aim of the study was to verify the hypothesis as to whether a larger input of riverine DOC 644 in the Arctic water could induce a higher DOC concentration in sea ice, which would promote 645 bacterial respiration, leading to a higher $\mathrm{pCO}_{2}$ in brine. Although the overall trend of $\mathrm{pCO}_{2}$ in 646 both mesocosm series strongly depends on the ice temperature (Figure 1) as a result of the effect 647 of brine concentration and brine dilution, the differences (SWR-SW) in observations and model 648 simulations support our hypothesis.

649 The difference of $\mathrm{pCO}_{2}$ between $\mathrm{SW}$ and $\mathrm{SWR}$ was much lower than the difference of $\mathrm{pCO}_{2}$ in 650 brine between the Arctic Ocean and the Southern Ocean. However, if we have added more 651 labile DOC instead of humic-rich riverine water to our mesocosms and if we extended the 652 duration of the experiment with lower air temperature, we may have observed larger differences 653 of DIC and $\mathrm{pCO}_{2}$, closer to those observed in natural conditions. The availability of more labile 654 autochthonous DOC may promote higher bacterial respiration and higher accumulation of $\mathrm{CO}_{2}$ 655 in ice. Further, extending the duration of the experiment to several months, with further 656 decrease of the ice temperature, would increase the respiration burden, reduce the ice 657 permeability, and therefore reduce gases and DIC losses through the ice.

658 Because the addition of riverine DOC to seawater causes larger $\mathrm{pCO}_{2}$ in ice, the Arctic Ocean, 659 which receives a large input of terrestrial DOC through rivers, might induce more positive (or 660 less negative) ice-air $\mathrm{CO}_{2}$ fluxes than the Southern Ocean, for the same environmental 661 conditions. Similarly, Arctic coastal waters might also be associated with a more positive (or 662 negative) ice-air $\mathrm{CO}_{2}$ fluxes than the central Arctic. This is at least true for the ice growth period when algal growth is limited, as considered by the absence of autochthonous DOC in our experiment. Algal growth would consume $\mathrm{CO}_{2}$ but will also produce labile autochtonous DOC that enhances bacterial production. Further experiments are therefore needed to refine the net impact of algal and bacterial growth on $\mathrm{pCO}_{2}$ in ice and on the inter-hemispheric differences.

667 The inter-hemispheric difference of $\mathrm{pCO}_{2}$ in ice and brine likely results from the impact of ice 668 temperature on the ice permeability and the buffering effect of the carbonate system, in addition 669 to the DOC input. Lower ice temperatures are associated with larger buffering effects, i.e., the increase of $\mathrm{pCO}_{2}$ in the ice interior in response to a given increase of DIC (due to bacterial respiration) would be enhanced. If the ice temperature is low enough so that the ice becomes 672 impermeable to gas exchange, the accumulation of $\mathrm{pCO}_{2}$ would have been more obvious, 673 resulting in the larger observed inter-hemispheric difference of $\mathrm{pCO}_{2}$ in ice and brine. On the 674 contrary, higher ice temperatures are associated with lower buffering effects and larger ice 
permeability. Exchange may occur through the ice, and offset the bacterial accumulation of

$676 \mathrm{CO}_{2}$. In our study, the impact of bacterial respiration on $\mathrm{pCO}_{2}$ was most obvious in the ice interior, because ice-air gas exchange and brine convection have offset the increase of $\mathrm{pCO}_{2}$ associated with bacterial respiration at the ice interfaces.

679 Considering the drastic decline in Arctic sea ice, we may also wonder how air-sea and air-ice $680 \mathrm{CO}_{2}$ fluxes may change in the future. If the ice cover is replaced more and more by open water, 681 the most common scenario is that air-sea $\mathrm{CO}_{2}$ fluxes increase, because gas exchange is more 682 efficient via an open sea surface than a semi-permeable ice cover. Our work highlighted the 683 fact that the dynamics regulating the $\mathrm{pCO}_{2}$ gradient will be different too. Due to the buffering 684 effect of the carbonate system, brine concentration makes the $\mathrm{pCO}_{2}$ more sensitive to DIC increase in ice than in seawater, and a small accumulation of DIC, due to low bacterial respiration may result in a large increase of $\mathrm{pCO}_{2}$ in the ice. At some specific locations, where bacterial activity is more intense in the ice than in the underlying water, the consequence of bacterial respiration on $\mathrm{pCO}_{2}$ in ice may be even more significant, especially when algal activity is limited. The interplay between gas transfer velocity and the $\mathrm{pCO}_{2}$ gradient needs to be taken into consideration while assessing the future evolution of the air-sea and air-ice $\mathrm{CO}_{2}$ fluxes in the polar regions.

692

\section{Acknowledgments}

694 We are grateful to two anonymous reviewers for their useful comments which have improved the quality of the manuscript. This study was supported by the European Community's 7th

696 Framework Programme through the grant to the budget of the Integrated Infrastructure 697 Initiative HYDRALAB-IV, Contract no. 261520. The authors would like to thank the Hamburg 698 Ship Model Basin (HSVA), Karl-Ulrich Evers and the rest of the ice tank crew, for the 699 hospitality, technical and scientific support and the professional execution of the test program 700 in the Research Infrastructure ARCTICLAB. The work was supported by a FiDiPro award by the Academy of Finland, the Walter and Andree Nottbeck Foundation, and the BIGSOUTH project funded by the Belgian Science Federal Policy Office. MK, SM and BD are respectively research fellows, postdoctoral researcher and research associate of the Fonds de la Recherche Scientique -FNRS. JZ was a F.R.S.-FNRS research fellow and is presently a BAEF Francqui Foundation research fellow. This is a MARE contribution $\mathrm{n}^{\circ} \mathrm{XXX}$.

\section{Contributions}


$708 \mathrm{JLT}, \mathrm{BD}, \mathrm{GD}, \mathrm{HK}, \mathrm{GK}$ planned and designed the experiment under the lead of DT; JZ, MK, 709 JLT, BD, GD and DT provided the data on sea ice physics and carbonate chemistry, HK, the 710 bacterial data, GK, the DOC data, and SM, the model simulations. JZ, BD, HK, SM wrote the 711 paper with the valuable comments and inputs from all the other co-authors. 
714 Figure 1. $\mathrm{pCO}_{2}$ measurements in sea ice and brine in the Arctic and Antarctica after Geilfus et 715 al. (2014), excluding the measurements where flooding was observed. The horizontal line 716 indicates a $\mathrm{pCO}_{2}$ of $400 \mathrm{ppm}$ - a reference value considering current atmospheric $\mathrm{pCO}_{2}$.

717 Figure 2. Brine volume fraction $(\mathrm{BrV}$, in \%) and Rayleigh number (Ra) in the SW and SWR 718 mesocosms during the experiment. The black dots are the data points from the sampling, while 719 the color in between results is from interpolation (natural neighbours in Surfer 8 (C) software) 720 (Zhou et al., 2014).

721 Figure 3. a) Bacterial respiration (BR_TdR), b) $\mathrm{DIC}_{7}$ and c) $\mathrm{pCO}_{2}$ in water and sea ice. Note that for sea ice, we plotted the median value of each ice core.

Figure 4. Bacterial respiration (BR_TdR) in ice in the SW and SWR mesocosms during the nmol C L $\mathrm{L}^{-1} \mathrm{~h}^{-1}$.

Figure 5. DIC 7 in ice of the SW and SWR mesocosms during the experiment, and the difference between both mesocosms. $\mathrm{DIC}_{7}$ is expressed in $\mu \mathrm{mol} \mathrm{C} \mathrm{kg}^{-1}$. Insignificant differences of $\mathrm{DIC}_{7}$ are set in white.

Figure 6. $\mathrm{pCO}_{2}$ in ice in the $\mathrm{SW}$ and $\mathrm{SWR}$ mesocosms during the experiment, and the difference between both mesocosms. $\mathrm{pCO}_{2}$ is expressed in ppm. Insignificant differences of $\mathrm{pCO}_{2}$ are set in white.

Figure 7. Relationship between $\mathrm{pCO}_{2}$ in ice and brine volume fraction. The circles are the data used to draw the fit (black curve), the other discrete symbols are not considered (see explanation in the text). The blue curves are the $95 \%$ confidence bands of the fit and the red dashed curve is the relationship predicted by CO2SYS (Lewis and Wallace, 1998).

Figure 8. Buffer factor of the carbonate system for decreasing temperature and related increase of salinity due to brine concentration/dilution in a closed system. Initial conditions was $\mathrm{S}=$ $35.17, \mathrm{~T}=-1.8^{\circ} \mathrm{C}, \mathrm{TA}=2578 \mu \mathrm{mol} \mathrm{kg}{ }^{-1}, \mathrm{DIC}=2450.4 \mu \mathrm{mol} \mathrm{kg} \mathrm{kg}^{-1}, \mathrm{pCO}_{2}=400 \mu \mathrm{atm} . \beta$ is provided for an increase of DIC of $20 \mu \mathrm{mol} \mathrm{kg}{ }^{-1}$.

Figure 9. (Clockwise) Temporal changes of the ice thickness, median ice temperature, median ice salinity, the standing stock of DIC and the median $\mathrm{pCO}_{2}$ in the ice. The dots refer to the measurements (white for SW and black for SWR), while the curves refer to the simulated results. The vertical dashed line shows the transition from ice growth to ice decay.

Figure 10 Modeled $\mathrm{DIC}_{7}$ in ice, in SW and SWR mesocosms, and the difference SWR minus SW, using a median bacterial respiration in ice associated with a BGE of 0.15 (Table 1).

Figure 11. Modeled $\mathrm{pCO}_{2}$ in ice, in SW and SWR mesocosms, and the difference SWR minus

747 SW, using a median bacterial respiration in ice associated with a BGE of 0.15 (Table 1).

748 Table 1. Calculated median bacterial respiration (BR) in ice in SW and SWR using different 749 bacterial growth efficiencies (BGE), the measured median difference of $\mathrm{pCO}_{2}$ and DIC (SWR 750 minus SW) during the experiment (Diff $\mathrm{pCO}_{2}$ and Diff $\mathrm{DIC}_{7}$ ), and the modeled difference of $751 \mathrm{pCO}_{2}$ and DIC for each set of BGE-dependent BR. 


\section{References}

754

755

756

757

758

759

760

761

762

763

764

765

766

767

768

769

770

771

772

773

774

775

776

777

778

779

780

781

782

783

784

785

786

787

788

Anderson, G.M., 1976. Error propagation by the Monte Carlo method in geochemical calculations. Geochim. Cosmochim. Acta 40, 1533-1538.

Aslam, S.N., Underwood, G.J.C., Kaartokallio, H., Norman, L., Autio, R., Fischer, M., Kuosa, H., Dieckmann, G.S., Thomas, D.N., 2012. Dissolved extracellular polymeric substances (dEPS) dynamics and bacterial growth during sea ice formation in an ice tank study. Polar Biol. 35, 661-676. doi:10.1007/s00300-011-1112-0

Baer, S., Connelly, T., Bronk, D., 2015. Nitrogen uptake dynamics in landfast sea ice of the Chukchi Sea. Polar Biol. 38, 781-797. doi:10.1007/s00300-014-1639-y

Brown, K.A., Miller, L.A., Davelaar, M., Francois, R., Tortell, P.D., 2014. Overdetermination of the carbonate system in natural sea-ice brine and assessment of carbonic acid dissociation constants under low temperature, high salinity conditions. Mar. Chem. 165, 36-45. doi:10.1016/j.marchem.2014.07.005

Copin-Montegut, C., 1988. A new formula for the effect of temperature on the partial pressure of CO2 in seawater. Mar. Chem. 25, 29-37. doi:10.1016/0304-4203(88)90012-6

Cox, G.F.N., Weeks, W.F., 1983. Equations for determining the gas and brine volumes in sea ice samples. J. Glaciol. 29, 306-316.

Crabeck, O., Delille, B., Thomas, D., Geilfus, N.-X., Rysgaard, S., Tison, J.-L., 2014. CO2 and $\mathrm{CH} 4$ in sea ice from a subarctic fjord under influence of riverine input. Biogeosciences 11, 6525-6538. doi:10.5194/bg-11-6525-2014

Del Giorgio, P., Cole, J.J., 1998. Bacterial growth efficiency in natural aquatic systems. Annu. Rev. Ecol. Syst. 29, 503-541.

Delille, B., 2006. Inorganic carbon dynamics and air-ice-sea CO2 fluxes in the open and coastal waters of the Southern Ocean. Université de Liège, Belgique.

Delille, B., Harlay, J., Zondervan, I., Jacquet, S., Chou, L., Wollast, R., Bellerby, R.G.J., Frankignoulle, M., Borges, A.V., Riebesell, U., Gattuso, J.P., 2005. Response of primary production and calcification to changes of $\mathrm{pCO} 2$ during experimental blooms of the coccolithophorid Emiliania huxleyi. Global Biogeochem. Cycles 19, 1-14. doi:10.1029/2004GB002318

Delille, B., Jourdain, B., Borges, A. V., Tison, J.-L., Delille, D., 2007. Biogas (CO2, O2, dimethylsulfide) dynamics in spring Antarctic fast ice. Limnol. Oceanogr. 52, 13671379. doi:10.4319/1o.2007.52.4.1367

Delille, B., Vancoppenolle, M., Geilfus, N.-X., Tilbrook, B., Lannuzel, D., Schoemann, V., Becquevort, S., Carnat, G., Delille, D., Lancelot, C., Chou, L., Dieckmann, G.S., Tison, J.-L., 2014. Southern Ocean CO2 sink: The contribution of the sea ice. J. Geophys. Res. Ocean. 119, 6340-6355. doi:10.1002/2014JC009941 
Dickson, A.G., Millero, F.J., 1987. A comparison of the equilibrium constants for the dissociation of carbonic acid in seawater media. Deep Sea Res. 34, 1733-1743. doi:10.1016/0198-0149(87)90021-5

Dieckmann, G.S., Nehrke, G., Papadimitriou, S., Göttlicher, J., Steininger, R., Kennedy, H., Wolf-Gladrow, D., Thomas, D.N., 2008. Calcium carbonate as ikaite crystals in Antarctic sea ice. Geophys. Res. Lett. 35, 35-37. doi:10.1029/2008GL033540

Dieckmann, G.S., Nehrke, G., Uhlig, C., Göttlicher, J., Gerland, S., Granskog, M.A., Thomas, D.N., 2010. Brief Communication: Ikaite (CaCO3.6H2O) discovered in Arctic sea ice. Cryosphere 4, 227-230. doi:10.5194/tc-4-227-2010

Dittmar, T., Kattner, G., 2003. The biogeochemistry of the river and shelf ecosystem of the Arctic Ocean: a review. Mar. Chem. 83, 103-120. doi:10.1016/S0304-4203(03)00105-1

DOE, 1994. Handbook of Methods for the Analysis of the Various Parameters of the Carbon Dioxide System in Sea Water; version2.

Eronen-Rasimus, E., Kaartokallio, H., Lyra, C., Autio, R., Kuosa, H., Dieckmann, G.S., Thomas, D.N., 2014. Bacterial community dynamics and activity in relation to dissolved organic matter availability during sea-ice formation in a mesocosm experiment. Microbiologyopen 3, 139-156. doi:10.1002/mbo3.157

Frankignoulle, M., 1994. A complete set of buffer factors for acid/base CO2 system in seawater. J. Mar. Syst. 5, 111-118. doi:10.1016/0924-7963(94)90026-4

Fuhrman, J.A., Azam, F., 1982. Thymidine incorporation as a measure of heterotrophic bacterioplankton production in marine surface waters: Evaluation and field results. Mar. Biol. 66, 109-120. doi:10.1007/BF00397184

Fuhrman, J.A., Azam, F., 1980. Bacterioplankton secondary production estimates for coastal waters of British Columbia, Antarctica, and California. Appl. Environ. Microbiol. 39, 1085-1095.

Geilfus, N.-X., Carnat, G., Dieckmann, G.S., Halden, N., Nehrke, G., Papakyriakou, T., Tison, J.-L., Delille, B., 2013. First estimates of the contribution of CaCO3 precipitation to the release of $\mathrm{CO} 2$ to the atmosphere during young sea ice growth. J. Geophys. Res. Ocean. 118, 244-255. doi:10.1029/2012JC007980

Geilfus, N.-X., Carnat, G., Papakyriakou, T., Tison, J.-L., Else, B., Thomas, H., Shadwick, E., Delille, B., 2012a. Dynamics of pCO2 and related air-ice CO2 fluxes in the Arctic coastal zone (Amundsen Gulf, Beaufort Sea). J. Geophys. Res. Ocean. 117, C00G10. doi:10.1029/2011JC007118

Geilfus, N.-X., Delille, B., Verbeke, V., Tison, J.-L., 2012b. Towards a method for high vertical resolution measurements of the partial pressure of $\mathrm{CO} 2$ within bulk sea ice. J. Glaciol. 58, 287-300. doi:10.3189/2012JoG11J071

Geilfus, N.-X., Tison, J.-L., Ackley, S.F., Galley, R.J., Rysgaard, S., Miller, L.A., Delille, B., 2014. Sea ice pCO2 dynamics and air-ice CO2 fluxes during the Sea Ice Mass Balance in 
the Antarctic (SIMBA) experiment - Bellingshausen Sea, Antarctica. Cryosph. 8, 23952407. doi:10.5194/tc-8-2395-2014

Giannelli, V., Thomas, D.N., Haas, C., Kattner, G., Kennedy, H., Dieckmann, G.S., 2001. Behaviour of dissolved organic matter and inorganic nutrients during experimental seaice formation. Ann. Glaciol. 33, 317-321. doi:10.3189/172756401781818572

Golden, K.M., Ackley, S.F., Lytle, V.I., 1998. The percolation phase transition in sea ice. Science (80-. ). 282, 2238-2241. doi:10.1126/science.282.5397.2238

Gosink, T.A., Pearson, J.G., Kelley, J.J., 1976. Gas movement through sea ice. Nature 263, $41-42$.

Goyet, C., Poisson, A., 1989. New determination of carbonic acid dissociation constants in seawater as a function of temperature and salinity. Deep Sea Res. 36, 1635-1654. doi:10.1016/0198-0149(89)90064-2

Gran, G., 1952. Determination of the Equivalence Point in Potentiometric Titrations. Part II. Analyst 77, 661-671.

Hansell, D., Carlson, C., Repeta, D., Schlitzer, R., 2009. Dissolved Organic Matter in the Ocean: A Controversy Stimulates New Insights. Oceanography. doi:10.5670/oceanog.2009.109

Helmke, E., Weyland, H., 1995. Bacteria in sea ice and underlying water of the eastern Weddell Sea in midwinter. Mar. Ecol. Prog. Ser. 117, 269-288. doi:10.3354/meps 117269

Hunke, E.C., Notz, D., Turner, A.K., Vancoppenolle, M., 2011. The multiphase physics of sea ice: a review for model developers. Cryosph. 5, 989-1009. doi:10.5194/tc-5-989-2011

Jørgensen, L., Stedmon, C. a., Kaartokallio, H., Middelboe, M., Thomas, D.N., 2015. Changes in the composition and bioavailability of dissolved organic matter during sea ice formation. Limnol. Oceanogr. 00, 00-00. doi:10.1002/lno.10058

Kaartokallio, H., 2004. Food web components, and physical and chemical properties of Baltic Sea ice. Mar. Ecol. Prog. Ser. 273, 49-63. doi:10.3354/meps 273049

Kirchman, D.L., Hill, V., Cottrell, M.T., Gradinger, R., Malmstrom, R.R., Parker, A., 2009. Standing stocks, production, and respiration of phytoplankton and heterotrophic bacteria in the western Arctic Ocean. Deep. Res. Part II Top. Stud. Oceanogr. 56, 1237-1248. doi:10.1016/j.dsr2.2008.10.018

Kotovitch, M., Moreau, S., Zhou, J., Goosse, H., Vancoppenolle, M., Dieckmann, G.S., Thomas, D.N., Tison, J.-L., Delille, B., n.d. Measurements of air-ice CO2 fluxes over experimental sea ice emphasize the role of bubbles in gas transport during ice growth, Elementa: Science of the Anthropocene. 
Krembs, C., Eicken, H., Deming, J.W., 2011. Exopolymer alteration of physical properties of sea ice and implications for ice habitability and biogeochemistry in a warmer Arctic. Proc. Natl. Acad. Sci. U. S. A. 108, 3653-8. doi:10.1073/pnas.1100701108

Kuparinen, J., Autio, R., Kaartokallio, H., 2011. Sea ice bacterial growth rate, growth efficiency and preference for inorganic nitrogen sources in the Baltic Sea. Polar Biol. 34, 1361-1373. doi:10.1007/s00300-011-0989-y

Lewis, E., Wallace, D.W.R., 1998. Program developed for CO2 system calculations.

Loose, B., McGillis, W.R., Perovich, D., Zappa, C.J., Schlosser, P., 2014. A parameter model of gas exchange for the seasonal sea ice zone. Ocean Sci. 10, 17-28. doi:10.5194/os-10$17-2014$

Loose, B., Schlosser, P., Perovich, D., Ringelberg, D., Ho, D.T., Takahashi, T., RichterMenge, J., Reynolds, C.M., Mcgillis, W.R., Tison, J.-L., 2011. Gas diffusion through columnar laboratory sea ice: implications for mixed-layer ventilation of $\mathrm{CO} 2$ in the seasonal ice zone. Tellus B 63, 23-39. doi:10.1111/j.1600-0889.2010.00506.x

Marion, G.M., 2001. Carbonate mineral solubility at low temperatures in the Na-K-Mg-Ca-HCl-SO4-OH-HCO3-CO3-CO2-H2O system. Geochim. Cosmochim. Acta 65, 18831896.

Mehrbach, C., Culbrtdon, C.H., Hawley, J.E., Pytkowicz, R.M., 1973. Measurement of the apparent dissociation constants of carbonic acid in seawater at atmospheric pressure. Limnol. Oceanogr. 18, 897-907. doi:10.4319/1o.1973.18.6.0897

Miller, L.A., Carnat, G., Else, B.G.T., Sutherland, N., Papakyriakou, T.N., 2011a. Carbonate system evolution at the Arctic Ocean surface during autumn freeze-up. J. Geophys. Res. 116, C00G04. doi:10.1029/2011JC007143

Miller, L.A., Papakyriakou, T.N., Collins, R.E., Deming, J.W., Ehn, J.K., Macdonald, R.W., Mucci, A., Owens, O., Raudsepp, M., Sutherland, N., 2011b. Carbon dynamics in sea ice: A winter flux time series. J. Geophys. Res. 116, C02028. doi:10.1029/2009JC006058

Moreau, S., Kaartokallio, H., Vancoppenolle, M., Zhou, J., Kotovitch, M., Dieckmann, G.S., Thomas, D.N., Goosse, H., Tison, J.-L., Delille, B., n.d. Closing the O2 and CO2 budget under a growing ice sheet - a laboratory investigation, Elementa: Science of the Anthropocene.

Moreau, S., Vancoppenolle, M., Delille, B., Tison, J.-L., Zhou, J., Kotovitch, M., Thomas, D.N., Geilfus, N.-X., Goosse, H., 2015. Drivers of inorganic carbon dynamics in firstyear sea ice: A model study. J. Geophys. Res. Ocean. 120, 471-495. doi:10.1002/2014JC010388

Moreau, S., Vancoppenolle, M., Zhou, J., Tison, J.-L., Delille, B., Goosse, H., 2014. Modelling argon dynamics in first-year sea ice. Ocean Model. 73, 1-18. doi:10.1016/j.ocemod.2013.10.004 
Müller, S., Vähätalo, A. V., Stedmon, C. a., Granskog, M. a., Norman, L., Aslam, S.N., Underwood, G.J.C., Dieckmann, G.S., Thomas, D.N., 2013. Selective incorporation of dissolved organic matter (DOM) during sea ice formation. Mar. Chem. 155, 148-157. doi:10.1016/j.marchem.2013.06.008

Nagata, T., Watanabe, Y., 1990. Carbon- and nitrogen-to-volume ratios of bacterioplankton grown under different nutritional conditions. Appl. Environ. Microbiol. 56, 1303-1309.

Nguyen, D., Maranger, R., 2011. Respiration and bacterial carbon dynamics in Arctic sea ice. Polar Biol. 34, 1843-1855. doi:10.1007/s00300-011-1040-z

Nguyen, D., Maranger, R., Tremblay, J.É., Gosselin, M., 2012. Respiration and bacterial carbon dynamics in the Amundsen Gulf, western Canadian Arctic. J. Geophys. Res. Ocean. 117, 1-12. doi:10.1029/2011JC007343

Nomura, D., Eicken, H., Gradinger, R., Shirasawa, K., 2010. Rapid physically driven inversion of the air-sea ice $\mathrm{CO} 2$ flux in the seasonal landfast ice off Barrow, Alaska after onset of surface melt. Cont. Shelf Res. 30, 1998-2004. doi:10.1016/j.csr.2010.09.014

Notz, D., Worster, M.G., 2009. Desalination processes of sea ice revisited. J. Geophys. Res. 114, C05006. doi:10.1029/2008JC004885

Notz, D., Worster, M.G., 2008. In situ measurements of the evolution of young sea ice. J. Geophys. Res. Ocean. 113, C03001. doi:10.1029/2007JC004333

Papadimitriou, S., Thomas, D.N., Kennedy, H., Haas, C., Kuosa, H., Krell, A., Dieckmann, G.S., 2007. Biogeochemical composition of natural sea ice brines from the Weddell Sea during early austral summer. Limnol. Oceanogr. 52, 1809-1823. doi:10.4319/1o.2007.52.5.1809

Pelegrí, S.P., Dolan, J., Rassoulzadegan, F., 1999. Use of high temperature catalytic oxidation (HTCO) to measure carbon content of microorganisms. Aquat. Microb. Ecol. 16, 273280. doi:10.3354/ame016273

Rivkin, R.B., Legendre, L., 2001. Biogenic carbon cycling in the upper ocean: effects of microbial respiration. Science (80-. ). 291, 2398-2400.

Rysgaard, S., Glud, R.N., Sejr, M.K., Bendtsen, J., Christensen, P.B., 2007. Inorganic carbon transport during sea ice growth and decay: A carbon pump in polar seas. J. Geophys. Res. 112, C03016. doi:10.1029/2006JC003572

Shadwick, E.H., Thomas, H., Chierici, M., Else, B., Fransson, A., Michel, C., Miller, L.A., Mucci, A., Niemi, A., Papakyriakou, T.N., Tremblay, J.-É., 2011. Seasonal variability of the inorganic carbon system in the Amundsen Gulf region of the southeastern Beaufort Sea. Limnol. Oceanogr. 56, 303-322. doi:10.4319/1o.2011.56.1.0303

Smith, R.E.H., Clement, P., 1990. Heterotrophic activity and bacterial productivity in assemblages of microbes from sea ice in the high Arctic. Polar Biol. 10, 351-357. doi:10.1007/BF00237822 
Vancoppenolle, M., Goosse, H., de Montety, A., Fichefet, T., Tremblay, B., Tison, J.-L., 2010. Modeling brine and nutrient dynamics in Antarctic sea ice: The case of dissolved silica. J. Geophys. Res. 115, C02005. doi:10.1029/2009JC005369

Zhou, J., Delille, B., Eicken, H., Vancoppenolle, M., Brabant, F., Carnat, G., Geilfus, N.-X., Papakyriakou, T., Heinesch, B., Tison, J.-L., 2013. Physical and biogeochemical properties in landfast sea ice (Barrow, Alaska): Insights on brine and gas dynamics across seasons. J. Geophys. Res. Ocean. 118, 3172-3189. doi:10.1002/jgrc.20232

Zhou, J., Delille, B., Kaartokallio, H., Kattner, G., Kuosa, H., Tison, J.-L., Autio, R., Dieckmann, G.S., Evers, K.-U., Jørgensen, L., Kennedy, H., Kotovitch, M., Luhtanen, A.-M., Stedmon, C.A., Thomas, D.N., 2014. Physical and bacterial controls on inorganic nutrients and dissolved organic carbon during a sea ice growth and decay experiment. Mar. Chem. 166, 59-69. doi:10.1016/j.marchem.2014.09.013 
Observations

Model

\begin{tabular}{|c|c|c|c|c|c|c|}
\hline & BR (SW) & BR (SWR) & Diff $\mathrm{pCO}_{2}$ & Diff $\mathrm{DIC}_{7}$ & Diff $\mathrm{pCO}_{2}$ & Diff $\mathrm{DIC}_{7}$ \\
\hline & nmol C L ${ }^{-1} h^{-1}$ & nmol C L ${ }^{-1} h^{-1}$ & ppm & $\mu \mathrm{mol} \mathrm{kg}^{-1}$ & ppm & $\mu \mathrm{mol} \mathrm{kg}^{-1}$ \\
\hline $\mathrm{BGE}=0.348$ & 10.0 & 24.7 & \multirow{3}{*}{13} & \multirow{3}{*}{2.8} & 8.3 & 0.9 \\
\hline $\mathrm{BGE}=0.2$ & 21.5 & 52.6 & & & 19.3 & 1.9 \\
\hline $\mathrm{BGE}=0.15$ & 30.4 & 74.6 & & & 31.9 & 2.7 \\
\hline
\end{tabular}


Fig. 1

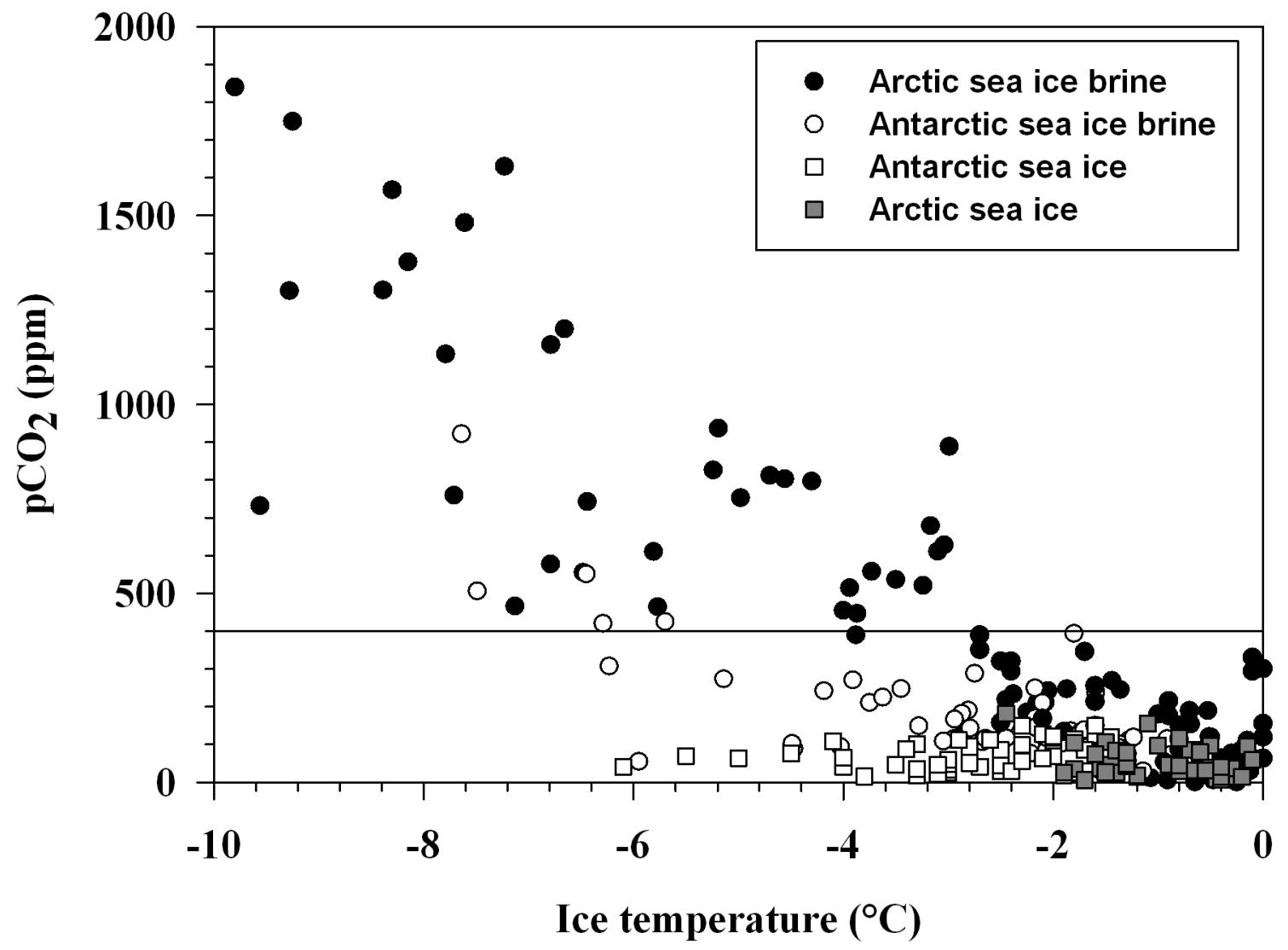




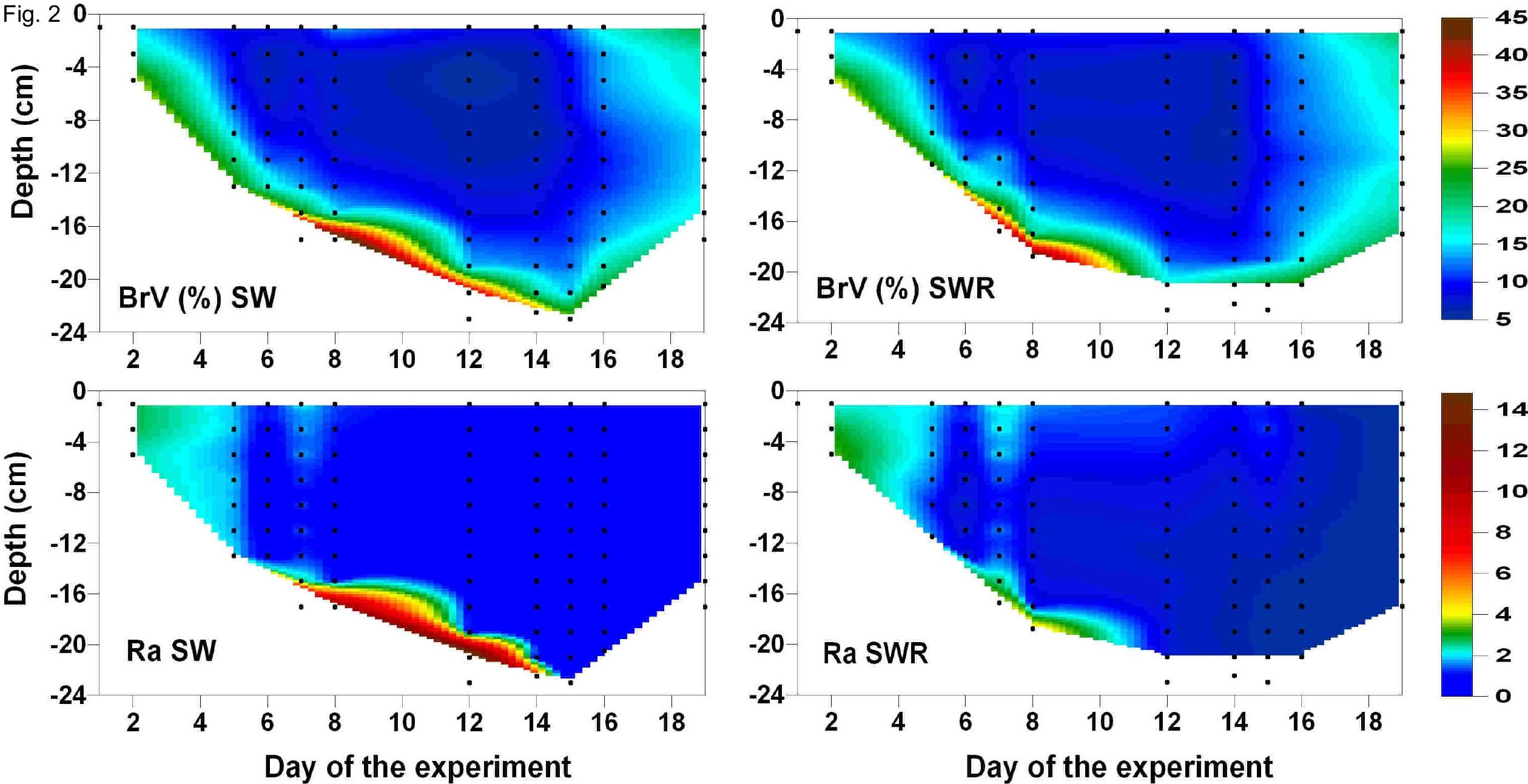



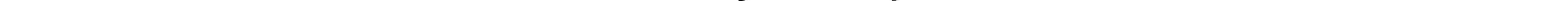

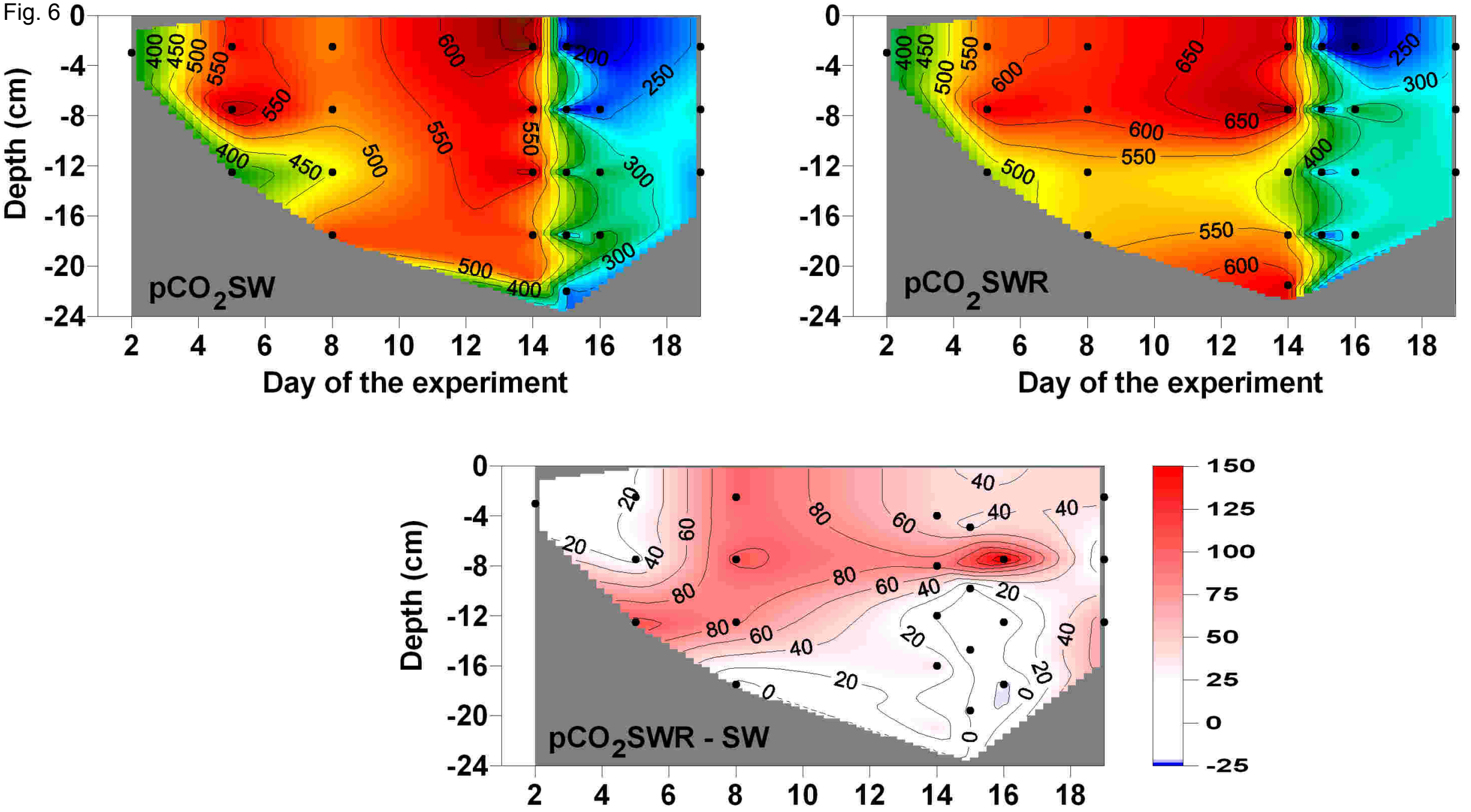
Day of the experiment 


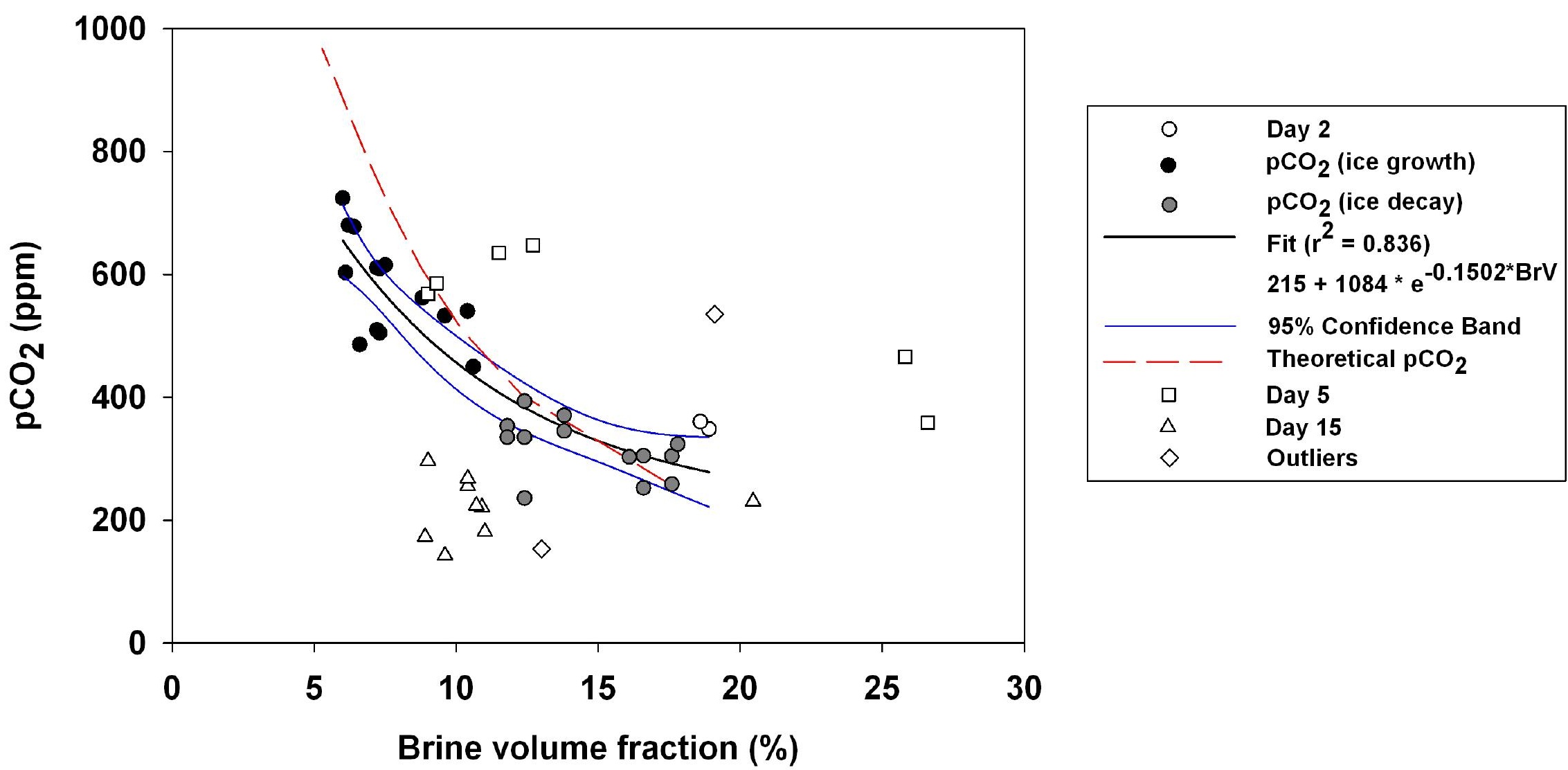


Fig. 8

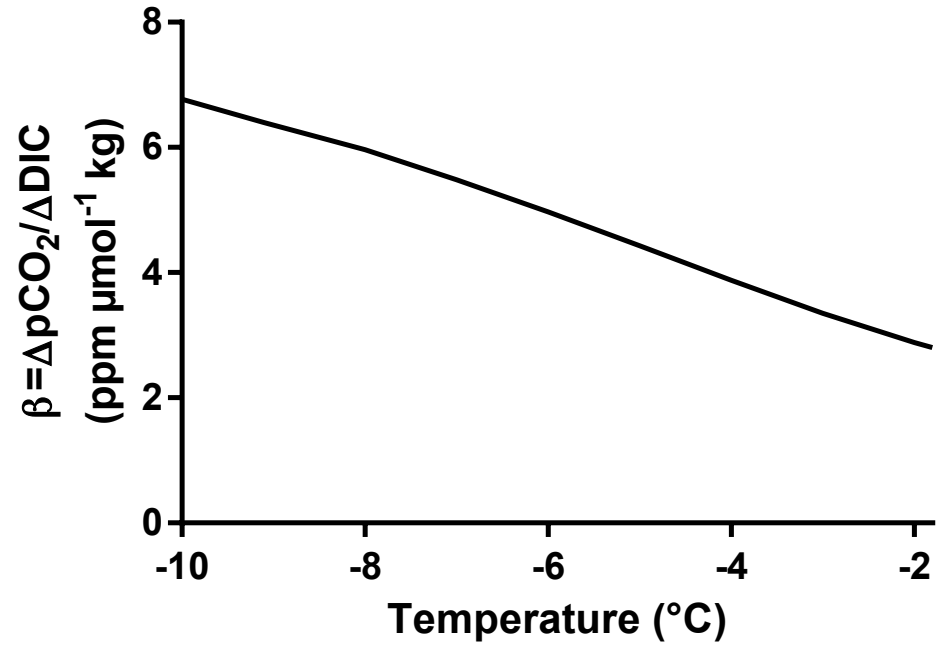




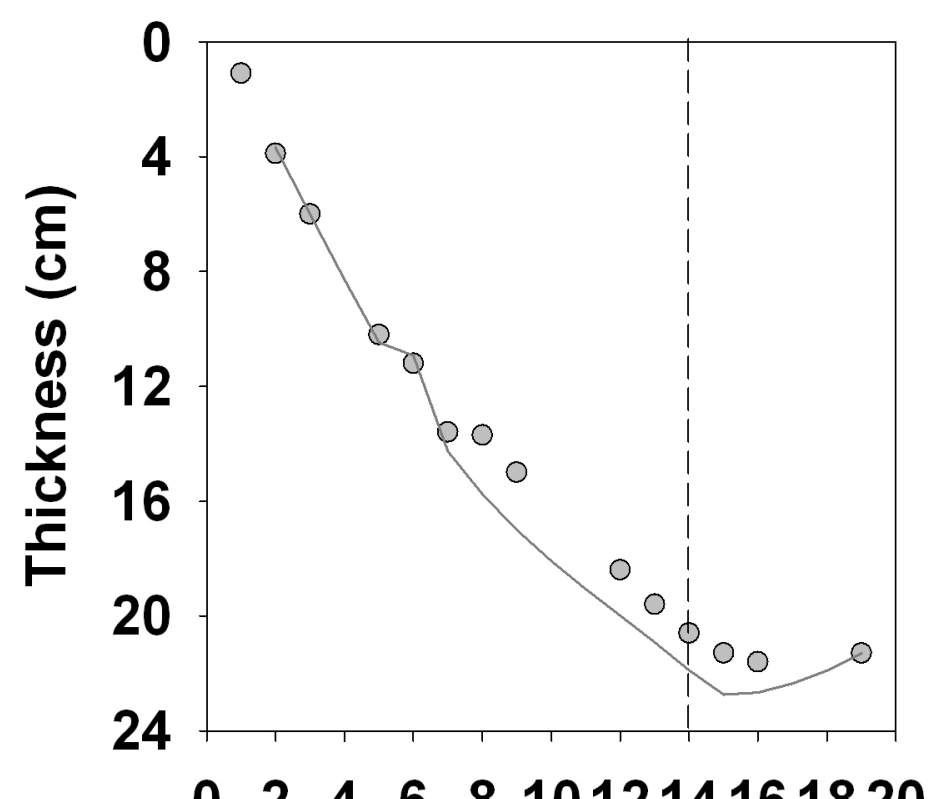

022468101214161820

Day of the experiment
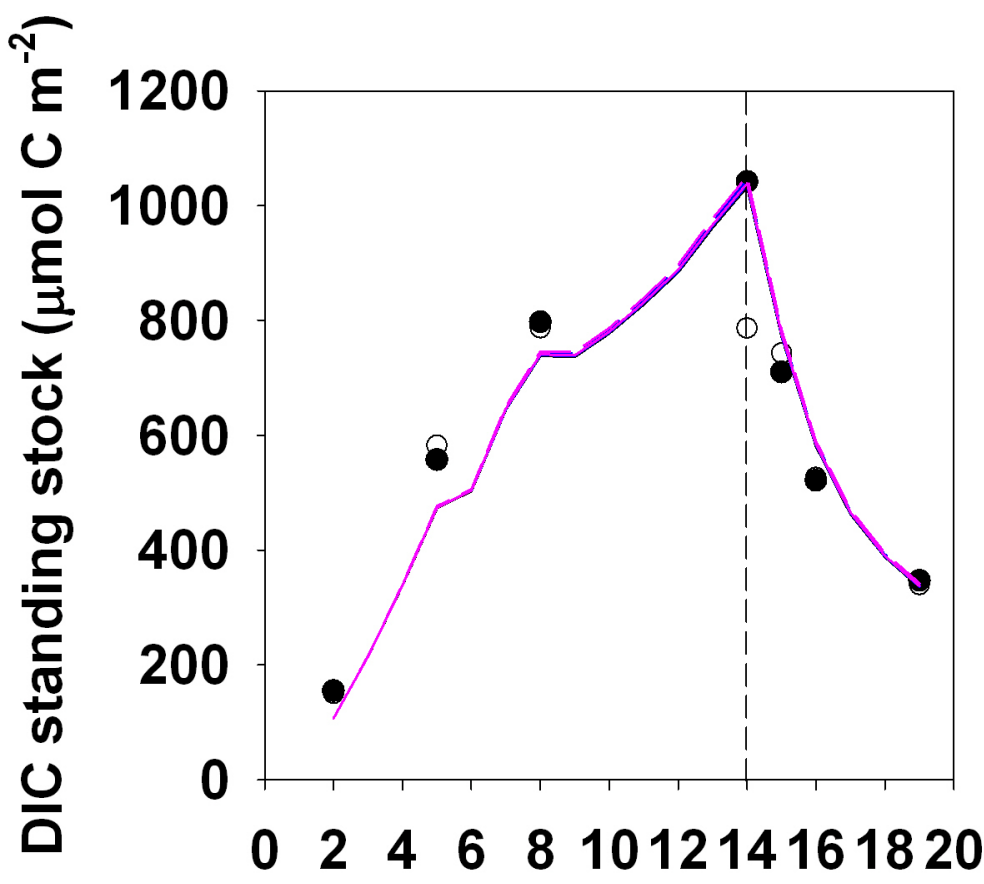

Day of the experiment

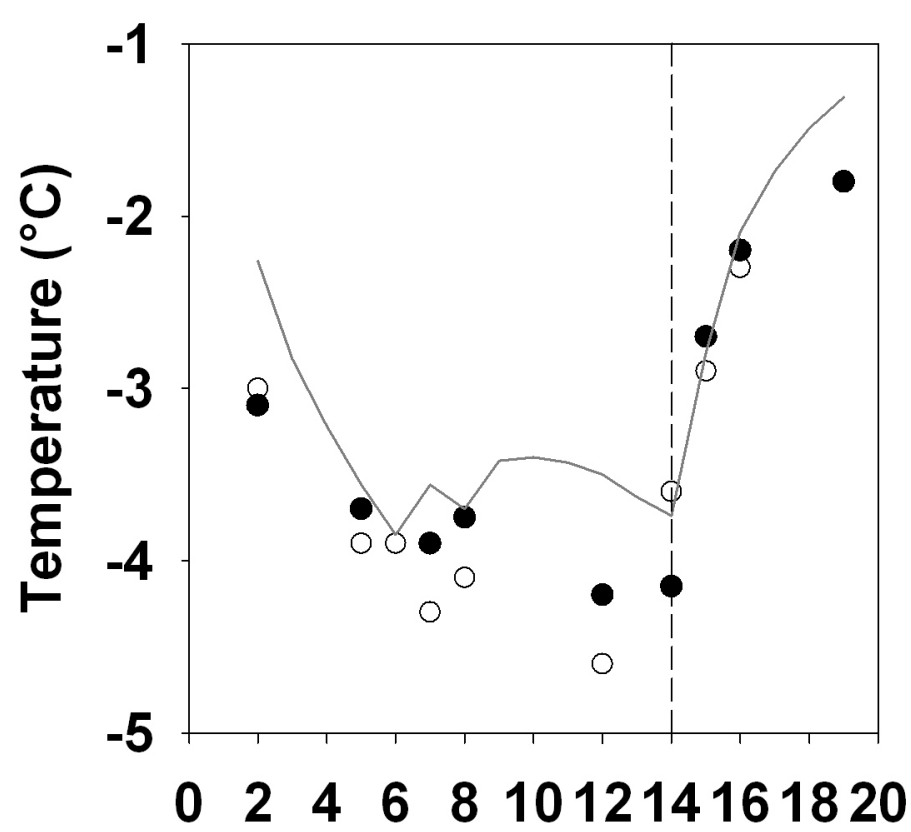

Day of the experiment

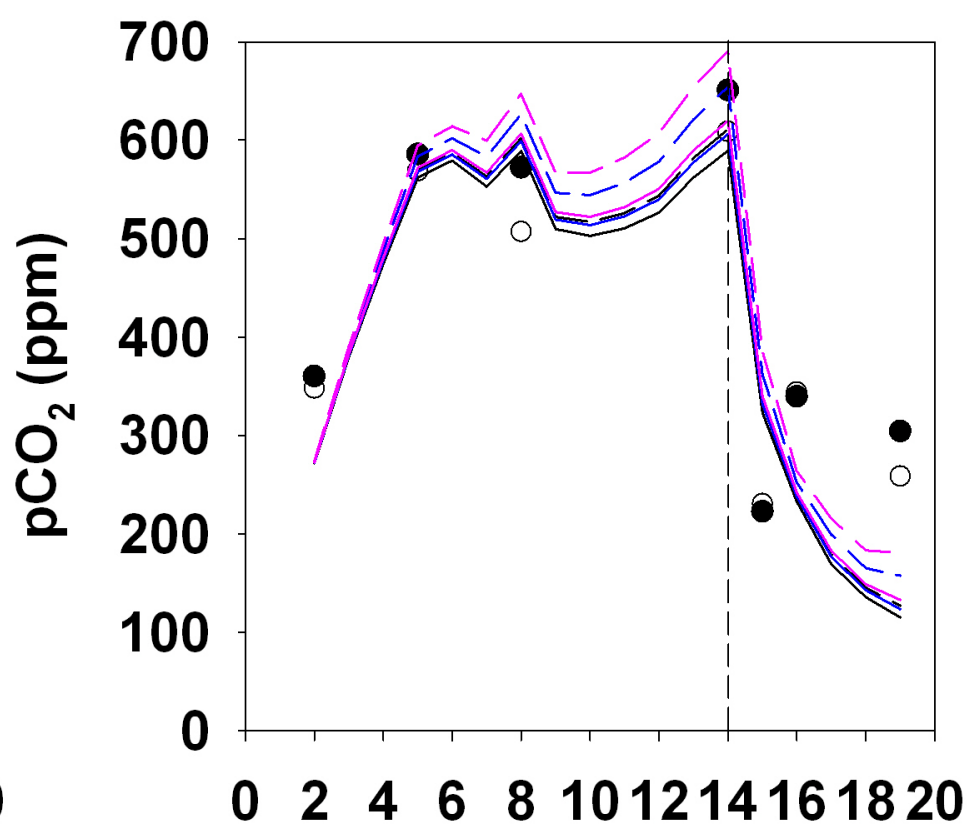

Day of the experiment

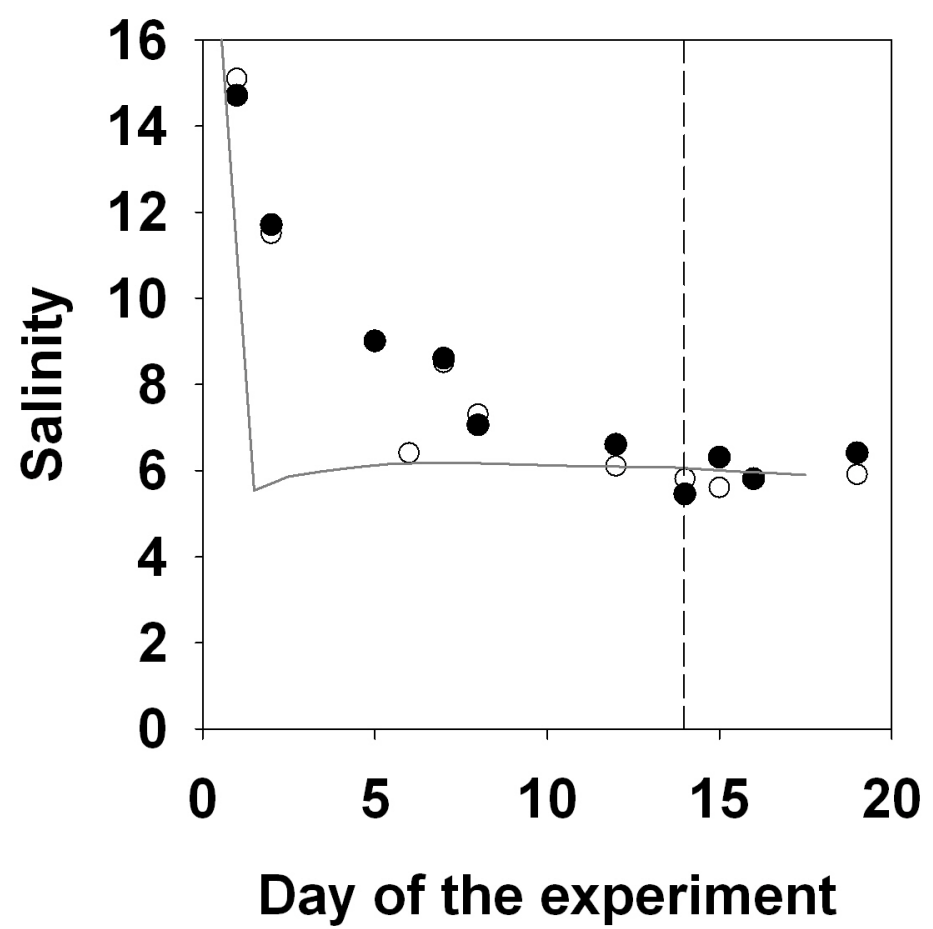

- Ice thickness Obs

- Ice SW

- Ice SWR

Modeled sea ice physics

Modeled Ice SW (BGE0.348)

Modeled Ice SWR (BGE0.348)

Modeled Ice SW (BGE0.2)

Modeled Ice SWR (BGE0.2)

Modeled Ice SW (BGE0.15)

Modeled Ice SWR (BGE0.15)
022468101214161820

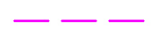

0 

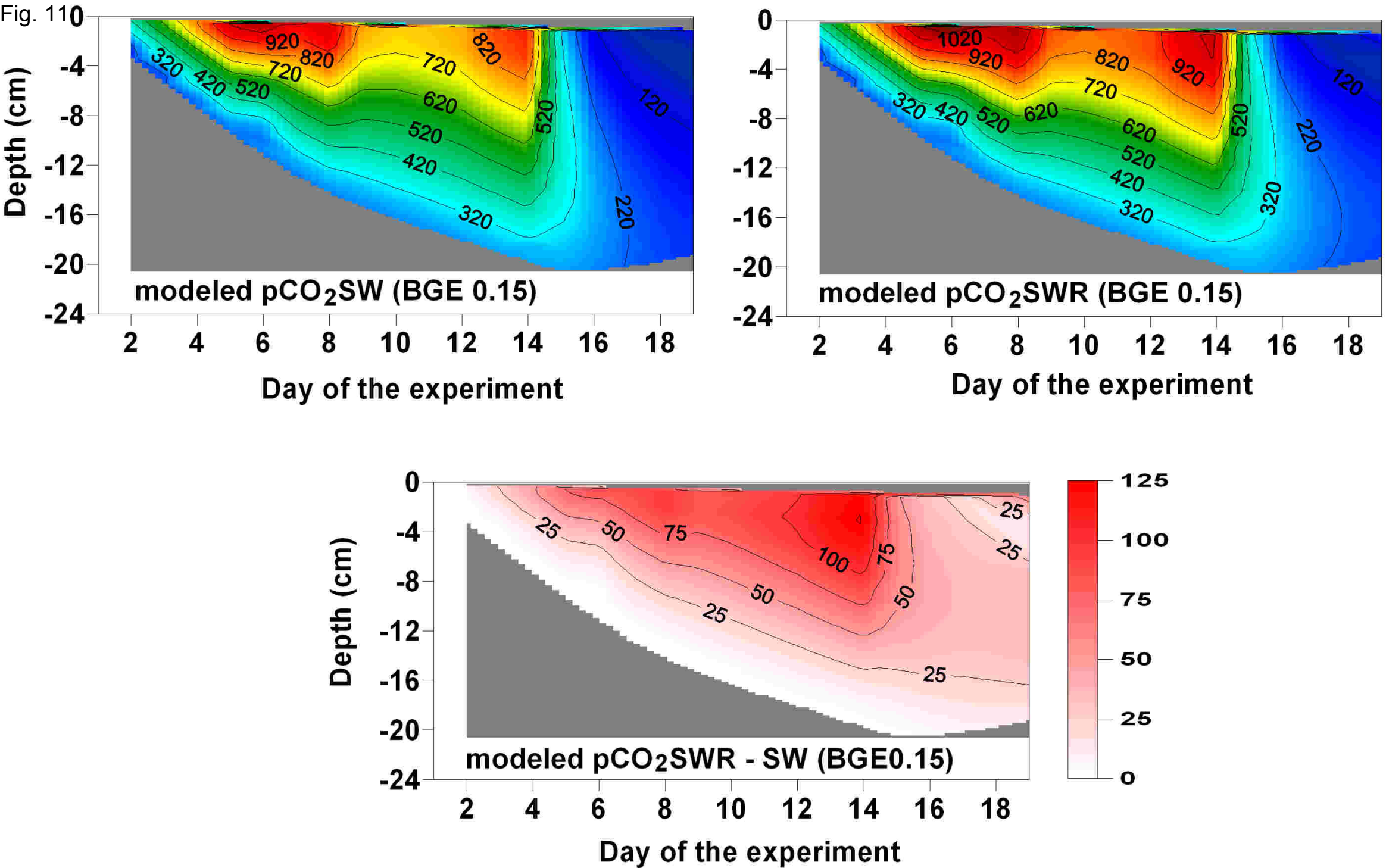